\title{
Palaeoenvironmental implications of aluminium phosphate-sulphate minerals in Early-Middle Triassic continental sediments, SE Iberian Range (Spain)
}

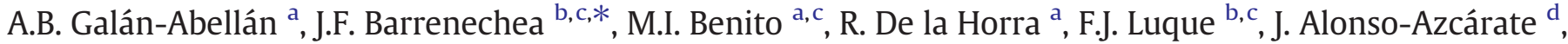 \\ A. Arche ${ }^{\mathrm{c}}$, J. López-Gómez ${ }^{\mathrm{c}}$, M. Lago ${ }^{\mathrm{e}}$ \\ a Departamento de Estratigrafía, Facultad de Geología, Universidad Complutense de Madrid, C/José Antonio Novais 12, 28040 Madrid, Spain \\ b Departamento de Cristalografía y Mineralogía, Facultad de Geología, Universidad Complutense de Madrid, C/José Antonio Novais 12, 28040 Madrid, Spain \\ ' Instituto de Geociencias (UCM, CSIC), C/José Antonio Novais 12, 28040 Madrid, Spain \\ d Facultad de Ciencias del Medio Ambiente, Universidad de Castilla-La Mancha, 45071 Toledo, Spain \\ e Departamento de Ciencias de la Tierra, Universidad de Zaragoza, C/Pedro Cerbuna s/n, 50009 Zaragoza, Spain
}

\section{A B S T R A C T}

The presence of Sr-rich aluminium-phosphate sulphate (APS) minerals in continental sedimentary rocks from the Cañizar and Eslida Formations along the eastern part of the Iberian Range (Spain) is considered as evidence of acidic and oxidising conditions during Early-Middle Triassic times. The formation of APS minerals occurred shortly after sedimentation, in early diagenetic stages, prior to the compaction of the sediments and most probably was related to the circulation of acidic meteoric waters. Such conditions might result from a sustained, damaged environment or from multiple environmental crises, but would have delayed the recovery of life after the end-Palaeozoic mass extinction. APS minerals occur as small disseminated and idiomorphic pseudo-cubic crystals ( 0.5 to $6 \mu \mathrm{m}$ long) or as massive and polycrystalline aggregates replacing fragments of fine-grained metamorphic rocks (mainly metapelites). Tex-tural data indicate that the formation of the APS minerals predated the quartz and illite cements, and that they resulted from the destabilisation of pre-existing minerals, as evidenced by the replacement of slate fragments by APS minerals and hematite and by the close association of the disseminated APS crystals and kaolinite with altered detrital mica plates. Electron microprobe analyses and X-ray diffraction study of the APS minerals indicate a rather homogeneous composition in different parts of the basin, corresponding to solid solutions among woodhouseite, svanbergite, crandallite and goyazite. The sources of strontium in the APS minerals remain unclear. Phosphorous was primarily supplied by dissolution of detrital phosphates under acidic conditions, and sulphur derives from the weathering of pyrite.

Keywords: APS minerals, Early-Middle Triassic, Life recovery, Continental sediments Iberian Range

\section{Introduction}

The end of the Permian period is characterised by the largest mass extinction ever recorded in marine and terrestrial sedimentary rocks (Erwin, 1994; Retallack, 1999; Erwin et al., 2002; Twitchett, 2006). The causes of this crisis are still debated (Erwin, 1993; Renne et al., 1995; Hallam and Wignall, 1997; Krull et al., 2000; Benton, 2003; Clapham et al., 2009), but the modified environmental conditions persisted during Early Triassic times, as evidenced by the slow recovery of life compared to other biotic crisis (Corsetti et al., 2005). In recent years there have been many papers focused on the study of the environmental changes that occurred during the Permian-Triassic transition (e.g., Payne et al., 2004; Erwin, 2006; Lehrmann et al., 2006), although only a few are referred to continental sedimentary rocks associated with fluvial systems (e.g., Renne et al., 1995; Retallack, 1999; Krull and Retallack, 2000; Twitchett et al., 2001; Benito et al., 2005; Galfetti et al., 2007; De la Horra et al., 2008; Metcalfe et al., 2009).

The present study reports the recognition of Sr-rich hydrated aluminium phosphate-sulphate (APS) minerals in the first sediments preserved after the Permian-Triassic transition within the SE Iberian Range (Spain). APS minerals are members of the alunite supergroup. The general formula for this isostructural group of minerals is $\left(\mathrm{M}^{+}, \mathrm{M}^{2+}\right)$ $\left[\mathrm{M}^{3+}{ }_{3}(\mathrm{OH})_{6}\left(\mathrm{TO}_{4}\right)_{2}\right]$, where $\mathrm{M}^{+}\left(\mathrm{Na}^{+}, \mathrm{K}^{+},\left(\mathrm{H}_{3} \mathrm{O}\right)^{+}\right)$and $\mathrm{M}^{2+}$ $\left(\mathrm{Ca}^{2+}, \mathrm{Pb}^{2+}, \mathrm{Ba}^{2+}, \mathrm{Sr}^{2+}, \mathrm{REE}\right)$ are large cations in 12 -fold coordination, $\mathrm{M}^{3+}$ sites are mainly occupied by $\mathrm{Al}^{3+}$ and $\mathrm{Fe}^{3+}$ in octahedral coordination, and $\left(\mathrm{TO}_{4}\right)^{\mathrm{x}-}$ anions are dominated by $\mathrm{P}^{5+}, \mathrm{S}^{6+}$ and $\mathrm{As}^{5+}$ (Jambor, 1999; Dutrizac and Jambor, 2000; Hawthorne et al., 2000).

APS minerals occur in a wide variety of lithologies, including igneous, metamorphic and sedimentary rocks. A review of the geology and environments of formation of these phases can be found in Dill (2001). Most of the occurrences within the sedimentary realm correspond to the 
sulphate-free phosphate (e.g., crandallite, goyazite) (Tripplehorn et al., 1991; Rasmussen, 1996) or to the phosphate-free sulphate (e.g., alunite, natroalunite) (Khalaf, 1990; Polyak and Güven, 1996) members. However, the intermediate phosphate-sulphate composition is a common feature in the few studies reporting the presence of APS minerals in continental sandstones (Spötl, 1990; Novak et al., 1997; Pe-Piper and Dolansky, 2005). APS minerals in these cases occur as accessory phases related to early diagenetic precipitation, associated with the circulation of meteoric waters. These minerals also occur in uranium unconformity-type deposits in Proterozoic sandstone basins like the Athabasca (Canada), and McArthur (Australia) ones, where a continuum between the diagenetic Sr-rich APS minerals of the barren sandstones and the LREE-rich compositions in the hydrothermally altered sandstones has been recognised (Gaboreau et al., 2005, 2007).

The aim of the study is to establish the timing, conditions and mechanisms of formation of the Sr-rich APS minerals in different horizons within the Cañizar and Eslida Formations, of Early-Middle Triassic age, in four sections along the SE Iberian Range. According to Dill (2001), APS minerals can locally provide much more information (Eh, pH activities, fluid pressure, etc.) on the origin of the parent rocks than the rock-forming minerals which make up the host rocks of the APS mineralisation themselves. Therefore, we shall discuss the implications of their presence in the context of the environmental conditions that prevailed during the recovery of life (Early-Middle Triassic), after the end Permian biotic crisis.

\section{Geological setting}

The study area is located in the south-eastern part of the Iberian Range, eastern Spain (Fig. 1a, b). The Iberian Range is a NW-SE linear structure formed by two main segments; the Aragonian and the Castillian Branches separated by the Cenozoic Calatayud-Teruel Basin. The present-day configuration of the Iberian Range was created by tectonic inversion of the extensional Mesozoic Iberian Basin in several compressive phases during the Alpine orogeny, mainly during Late Oligocene-Early Miocene (van Wees et al., 1998; De Vicente et al., 2009; Vargas et al., 2009), and resulted in thin-skinned deformation with a main detachment level in the evaporite Upper Triassic Keuper facies. The development of the Iberian Basin started during the Early Permian and is related to the opening of two rift systems: the Iberian rift during the Middle Permian-Early Triassic, with a NW-SE trend, and the Norwegian-Greenland rift mainly during the Anisian, with a NNESSW trend (Ziegler, 1988; Arche and López-Gómez, 1996; Ziegler and Sampfli, 2001). During short phases of tectonic evolution the Iberian Basin, developed on low-metamorphic Hercynian rocks, was filled by continental alluvial sediments. Later on, the westward propagation of the Tethys in the Middle Triassic resulted in a first marine transgression, with marine limestones (Muschelkalk facies) onlapping the previous continental sediments (Sopeña et al., 1988; López-Gómez and Arche, 1993; López-Gómez et al., 2002).

The Triassic sediments of central and eastern Spain can be generally defined by the classic "germanic trilogy": Buntsandstein, Muschelkalk and Keuper, capped by a Late Triassic-Early Jurassic carbonate-evaporite complex. A closer look at the sedimentary record reveals a much more complex distribution of facies and large thickness variations due to differential rates of extension during the syn-sedimentary extensional tectonics and the alternation of coeval transgressive-regressive marine cycles (Virgili et al., 1977; Ramos, 1979; Sopeña et al., 1988; López-Gómez and Arche, 1993; López-Gómez et al., 2002; Arche et al., 2004; Sánchez-Moya and Sopeña, 2004; Vargas et al., 2009). The sedimentary record of these rocks has been subdivided into eight stratigraphical units (Fig. 1), not always present at every location, separated by angular unconformities and hiatuses. The six lower units (López-Gómez and Arche, 1993; Arche et al., 2004) consist of continental alluvial sediments (Fig. 1c) but only the third, fourth and fifth ones are of interest in this paper.
The present study is based on a detailed analysis of the top of the Alcotas Formation and the Cañizar and Eslida Formations (Late PermianMiddle Triassic) and includes four stratigraphic sections in the proximity of the Garaballa, Talayuelas, Gátova and Benicassim villages (Fig. 1).

The Alcotas Formation consists of red mudstones, sandstones and conglomerates (López-Gómez and Arche, 1993; De la Horra et al., 2012) and it has been interpreted as deposits of sandy braided and isolated meandering fluvial deposits with extensive floodplains, high avulsion rate and temporary shallow lakes (Arche and López-Gómez, 2005, 2006). The age of the unit is Late Permian (Thüringian sensu Visscher, 1971, or Tatarian, sensu Gorsky et al., 2003) (Doubinger et al., 1990; López-Gómez et al., 2005). In a recent work, De la Horra et al. (2012) conclude that a Middle Permian age could be accepted for the lower half of the Alcotas Formation.

The Early-Middle Triassic continental rocks in the study area consist of red to pink sandstones (Cañizar Formation), and red mudstones and sandstones (Eslida Formation) from base to top, respectively.

The Cañizar Formation is 80 to $170 \mathrm{~m}$ thick and averages $120 \mathrm{~m}$ in the study area (Fig. 2). The upper contact in the western part of the study area is represented by an unconformity that separates the Cañizar Formation from the overlying dolomites of peritidal origin (Muschelkalk facies). Eastward of the study area the Eslida and Marines Formations, of alluvial and estuarine origin respectively, are transitionally or with a hiatus deposited over the Cañizar Formation (Fig. 1b). The Cañizar Formation is mainly constituted by red to pink arkoses, although subarkoses and quartzarenites are also present. Following sedimentological criteria, it can be divided into six subunits (López-Gómez and Arche, 1993; López-Gómez et al., 2012) that are shown in Fig. 2 separated by dashed lines. Fine-grained sediments include small angular to subrounded quartz and albite grains embedded in a matrix composed of illite and hematite (Alonso-Azcárate et al., 1997; Benito et al., 2005). No fossil remains have been found up to now except some badly preserved, undetermined plant remains and one isolated tetrapod footprint in the upper third of the Formation (Gand et al., 2010) and one pollen and spore association at the top of the unit (Doubinger et al., 1990). The Cañizar Formation represents the evolution of laterally unconfined, superimposed sandy braided fluvial sequences with dominant development of bar and channel complexes with a unidirectional palaeocurrent trend pointing to S and SE and some local aeolian reworking (López-Gómez and Arche, 1993; Arche and López-Gómez, 2005; López-Gómez et al., 2011, 2012). Drainage during deposition was parallel to the basin axis and there is no evidence of even minor transverse streams feeding into the main fluvial system, an indication that the source area was far away to the NW.

There are not enough data for establishing a precise age for the whole Cañizar Formation. Doubinger et al. (1990) dated as Aegean (early Anisian) the upper part of the Cañizar Formation by means of palynological studies. Recently, López-Gómez et al. (2012) consider the base of the Cañizar Formation as late Smithian (Lower Triassic) based on comparisons with other time-equivalent units of southern and central Europe described in Durand (2006) and Bourquin et al. (2007, 2011).

The Eslida Formation is up to $660 \mathrm{~m}$ thick, although it shows remarkable thickness variations, ranging between 22 and $104 \mathrm{~m}$ in the Benicasim and Gátova sections, respectively. It is constituted by red mudstones with intercalated arkoses. This formation is not present in the Garaballa and Talayuelas sections (Fig. 2), because it occurs exclusively within a narrow strip along the east and southeast of the Iberian Basin, where subsidence was more important during the Anisian (Arche and López-Gómez, 1996). Arche and López-Gómez (1999) distinguished six alluvial sequences within this formation. The first five were related to a period of rapid subsidence, which allowed the development of sandy braided fluvial systems, with ephemeral lakes on the flood plains and carbonate palaeosol profiles. Most of the palaeocurrent point to the SE. The sixth alluvial sequence corresponds to a stage of lower subsidence that resulted in the abandonment of the alluvial systems and the beginning of a marine transgression (Arche and 


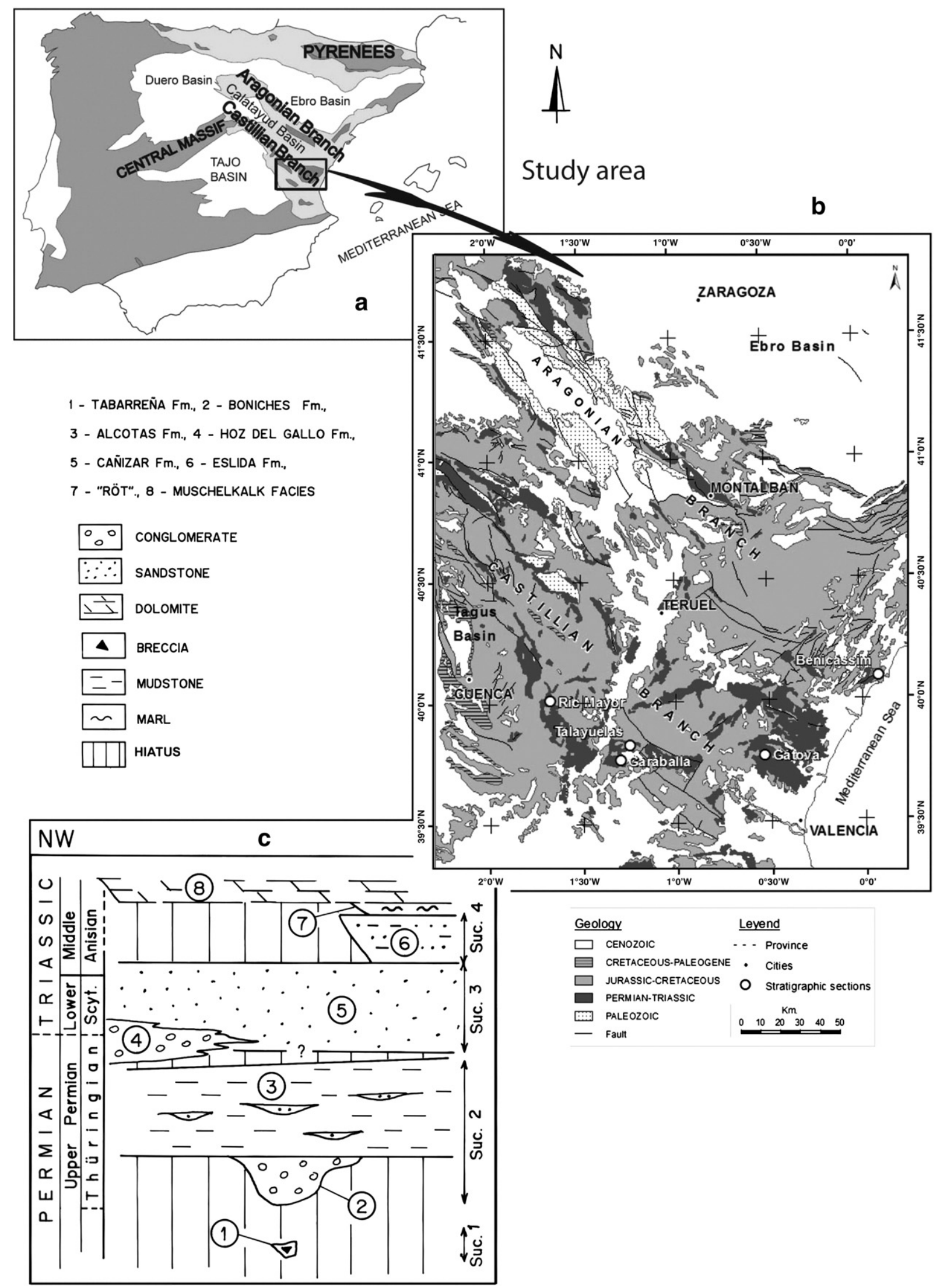

Fig. 1. a) Geological sketch of the Iberian Peninsula. b) Geological map of the SE Iberian Range and location of the studied sections. c) Stratigraphical framework of the different formations defined for the study area on a regional scale. 


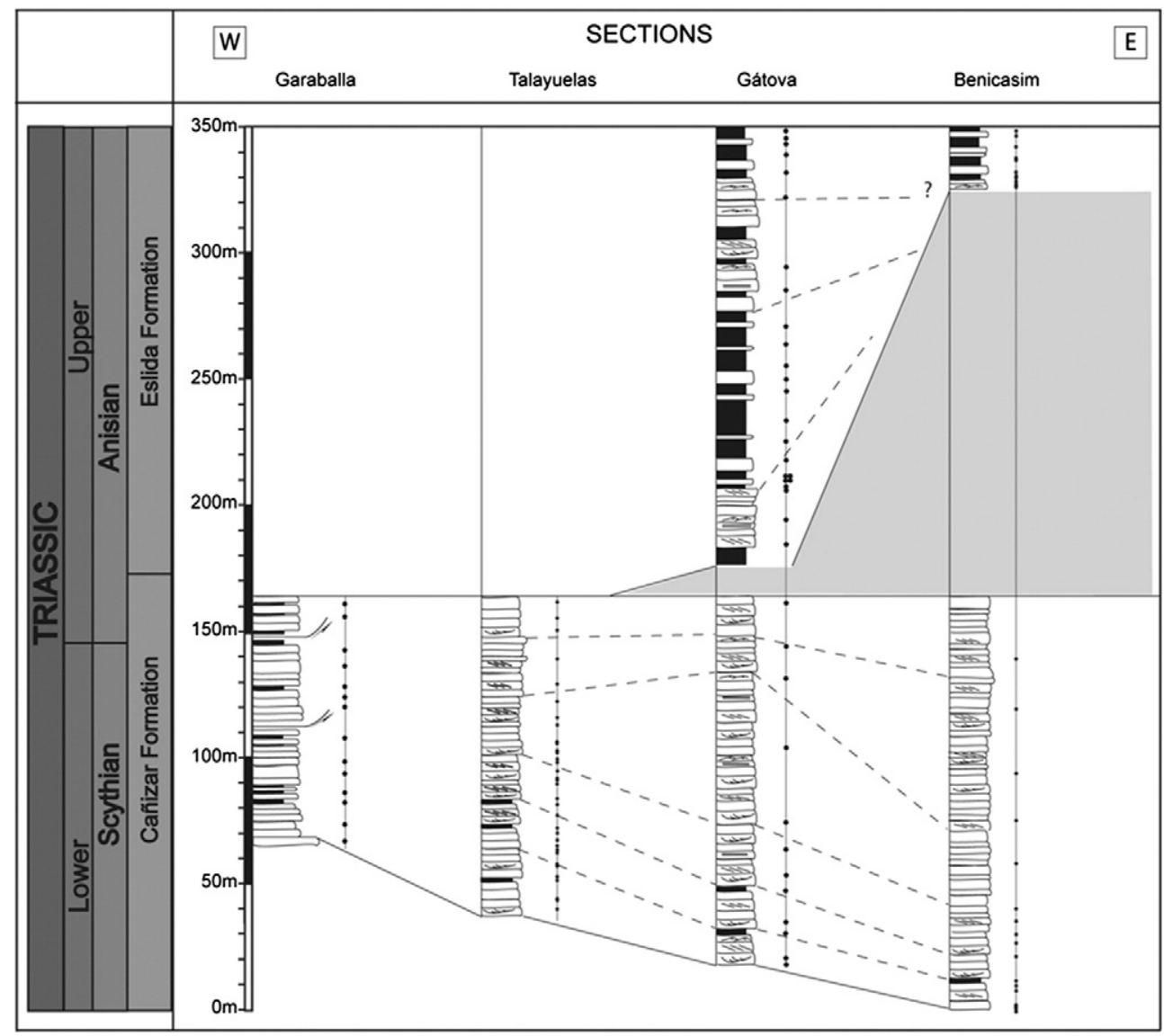

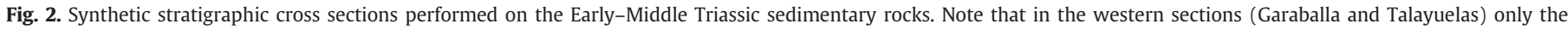

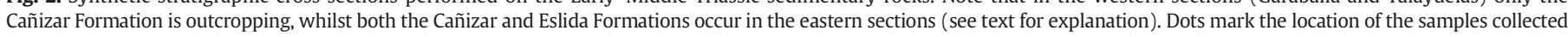
along the sections.

López-Gómez, 1999). The lowermost sequences occur in the GátovaEslida area where subsidence was more important, whilst the uppermost sequences show a more expansive character, covering laterally areas with lesser subsidence. They were deposited on an important hiatus at the top of the Cañizar Formation (Fig. 2).

In spite of the poor biostratigraphic data for the Eslida Formation, the age of this formation has been deduced from the data of the underand overlying units. As mentioned before, the top of the underlying Cañizar Formation is Aegean (early Anisian) and the ages of the overlying Marines and Landete Formations are Anisian (Doubinger et al., 1990) based on palynological associations, and Pelsonian-Illirian (Anisian) based on foraminifera associations (Márquez et al., 1994; Escudero-Mozo et al., 2012), respectively. Therefore, an AegeanPelsonian (Anisian) age is deduced for the Eslida Formation and most or all of the formation was deposited during the early Anisian over a maximum period of $2.5 \mathrm{Ma}$.

\section{Materials and methods}

One hundred and thirteen samples from the Cañizar and Eslida Formations were collected along the Garaballa, Talayuelas, Gátova and Benicasim stratigraphic cross-sections (Figs. 1a, 2). Red siltstones and mudstones from the top of the Alcotas Formation have been studied in the four cross-sections. Samples from the Cañizar Formation were collected from pink sandstone bodies of variable thickness $(0.5$ to $3 \mathrm{~m})$ with intercalated siltstone and mudstone lenses ( 5 to $20 \mathrm{~cm}$ thick) of limited lateral extension. The Eslida Formation is only present in the Gátova and Benicasim sections, where samples of red and violet mudstone, siltstone and sandstone have been collected.
Bulk mineralogy of mudstone and siltstone samples was obtained by X-ray diffraction (XRD) after grinding and homogenisation of the samples to $<53 \mu \mathrm{m}$. Random-oriented powders were examined on a Siemens Kristalloflex 810 diffractometer, using $\mathrm{Cu}-\mathrm{K} \alpha$ radiation at $30 \mathrm{kV}$ and $40 \mathrm{~mA}$, a step size of $0.03\left({ }^{\circ} 2 \theta\right)$, and time per step of $1 \mathrm{~s}$ (scan rate of $1.8^{\circ} 2 \theta / \mathrm{min}$ ). The clay mineral composition was determined on oriented aggregates of the $<2 \mu \mathrm{m}$ fraction obtained by sedimentation from an aqueous suspension onto glass slides. In some cases they underwent thermal treatment at $550{ }^{\circ} \mathrm{C}$ for $2 \mathrm{~h}$ and solvation with ethylene glycol (EG). A slower scan rate $\left(1.2^{\circ} 2 \theta / \mathrm{min}\right)$ was used between $2^{\circ}$ and $13^{\circ} 2 \theta$ in order to get better defined peaks. Random-oriented powders of the $<2 \mu \mathrm{m}$ fraction obtained as described above were also run in samples containing aluminium-phosphate sulphates (APS minerals), since these minerals concentrate in the clay size fraction.

In order to determine the intensity of the post-sedimentary processes that affected these samples, the full-width-half-maximum (FWHM) of the illite $10 \AA$ reflection (the so-called Kübler index, KI), was measured on the diffraction patterns of the $<2 \mu \mathrm{m}$ air-dried oriented aggregates. Our raw data were recalculated after calibration using reference polished slate slabs according to the procedure suggested by Kisch et al. (2004). The raw data can be transformed by the formula: $y=1.0059 \times-0.0493$. Therefore, the lower and upper limits of the anchizone are 0.38 and $0.21^{\circ} \Delta 2 \theta$, respectively.

Petrographic microscopy was used for the study and classification of sandstones following the scheme of Pettijohn (1975) and to complement the mineralogical characterisation of wackes and mudstones. A more detailed study of the textural and morphological features of the minerals was performed on gold-coated chips and on carbon-coated polished thin sections of selected samples in a JEOL 6400 scanning 
electron microscope (SEM), equipped with an energy dispersive spectrometer (EDS).

Electron microprobe analyses (EMPA) were performed on a JEOL JXA-8900 M WD/ED. All analyses were conducted with an accelerating voltage of $15 \mathrm{kV}$ and a spot size of $1 \mu \mathrm{m}$. Back-scattered electron microscope (BSEM) images were taken on the microprobe and helped to obtain textural information. The analyses of micas were recalculated on the basis of 22 oxygen atoms. Iron was considered as ferrous. Elemental mapping (Sr, P and S) was carried out on selected square areas (50 to $400 \mu \mathrm{m}$ long) to determine the distribution of the aluminium-phosphate sulphate crystals in these samples. Structural formulae of the APS minerals were calculated on the basis of 11 oxygen atoms.

\section{Results}

\subsection{Rock-forming minerals}

Random-oriented powders of samples analysed by XRD in the Alcotas, Cañizar and Eslida Formations contain quartz, mica, K-feldspar and hematite. In addition, strontium-rich aluminium phosphate sulphate minerals (APS minerals) are detected on XRD traces from samples of the Cañizar and Eslida Formations.

The petrographic study reveals that sandstones from both the Cañizar and Eslida Formations correspond to quartz-arenites, and subarkoses, although a few samples from the Cañizar Formation fall within the sub-lithic arenite field. Skeleton grains of these rocks include quartz, K-feldspar, lithic fragments of slates and phyllites commonly replaced by strontium-rich aluminium phosphate sulphate minerals (APS minerals), detrital mica, and accessory phases like rutile, zircon, ilmenite, monazite, apatite, tourmaline and less frequently xenotime within a clay matrix formed by illite, hematite and kaolinite in some samples. Quartz grains are rather well sorted, and range between sub-rounded to sub-angular. A thin film of iron oxide covers many of the quartz grains, which in addition are joined by syntaxial quartz cements. No primary porosity has been recognised, and the secondary porosity is filled with kaolinite, quartz, illite and iron oxide cements.

K-feldspars are frequently corroded (Fig. 3a) and partially replaced by kaolinite, illite and APS minerals. Electron microprobe analyses (EMPA) show no apparent compositional variations between feldspars from the Alcotas, Cañizar and Eslida Formations, with $\mathrm{Na} /(\mathrm{Na}+\mathrm{K})$ ratios ranging from 0.02 to 0.06 . The average structural formula is $\mathrm{K}_{0.96}$ $\mathrm{Na}_{0.04}\left(\mathrm{Al}_{1.02} \mathrm{Si}_{2.98}\right) \mathrm{O}_{8}$.

Rutile, zircon, ilmenite, monazite, apatite, xenotime and tourmaline are present as accessory minerals. BSEM images show that detrital xenotime and apatite grains (up to $50 \mu \mathrm{m}$ large) are rather abundant in these samples. However, within the Cañizar Formation they are frequently present as strongly corroded crystals (Fig. 3b, c). Rutile occurs as disseminated sub-idiomorphic crystals ( 30 to $40 \mu \mathrm{m}$ ) and as small (up to $2 \mu \mathrm{m}$ ) grains concentrated between altered biotite plates in samples from both formations. Zircon is present as elongated subidiomorphic crystals or as sub-rounded and fractured grains, ranging in size between 20 and $180 \mu \mathrm{m}$, and typically showing concentric zoning (Fig. 3d). Small relics of pyrite have been observed in a few samples. Moreover, many sandstone layers from the Benicasim section show abundant moulds of small and highly oxidised idiomorphic pyrite crystals (1-3 mm long).

Detrital micas occur as elongated and platy crystals (60 to $650 \mu \mathrm{m}$ in length) showing preferred orientation and surrounding quartz grains and lithic fragments. Large muscovite plates (up to $3 \mathrm{~mm}$ ) are accumulated on the surface of fine-grained sandstone layers from the Cañizar Formation, giving a micaceous appearance to the rock. Average structural formulae determined by EMPA for detrital biotite and muscovite from these samples can be written as $\left(\mathrm{K}_{1.80} \mathrm{Na}_{0.06} \mathrm{Ca}_{0.02}\right)\left(\mathrm{Fe}_{2.47}\right.$

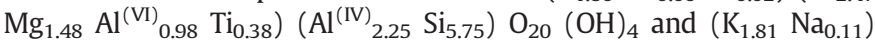
$\left(\mathrm{Fe}_{0.11} \mathrm{Mg}_{0.12} \mathrm{Al}^{(\mathrm{VI})}{ }_{3.69} \mathrm{Ti}_{0.06}\right)\left(\mathrm{Al}^{(\mathrm{IV})}{ }_{1.69} \mathrm{Si}_{6.31}\right) \mathrm{O}_{20}(\mathrm{OH})_{4}$, respectively.

In the Benicasim section, large detrital mica crystals show partial replacement by kaolinite and APS minerals and result in alternating bands of stacked mica and kaolinite (Fig. 4a, b). The edges of these partially replaced micas frequently open in a fan-shaped termination. Besides, booklets of dickite with no preferred orientation grow totally replacing the earlier platy kaolinite (Fig. 4c).

Most of the clay minerals from the matrix come from the alteration of lithic fragments, detrital micas and feldspar grains. The XRD patterns of oriented aggregates of the clay fraction contain illite, hematite and less frequently kaolinite, which is especially abundant in the Benicasim cross-section. Illite occurs as flakes (2-10 $\mu \mathrm{m}$ long) partially replacing previous feldspar grains or resulting from the illitisation of dickite, as described by Martín-Martín et al. (2007) in samples from the Benicasim section. The presence of reflections at $4.44 \AA, 4.12 \AA$ and $3.43 \AA$ indicates that kaolinite has been extensively transformed to dickite, as previously noticed by Martín-Martín et al. (2007). The Kübler index data for illite in these samples range between 0.43 and $0.86^{\circ} \Delta 2 \theta$ and are clearly indicative of diagenetic conditions.

\subsection{APS minerals}

\subsubsection{Textural relationships}

APS minerals are present in all the suited samples of sandstones, siltstones and mudstones from both the Cañizar and the Eslida Formations, but they have not been found in the underlying Alcotas Formation. The APS minerals occur as 1) small disseminated and idiomorphic pseudo-cubic crystals, 0.5 to $6 \mu \mathrm{m}$ large (Figs. $4 \mathrm{a}-\mathrm{d}, 5$ ) or as 2 ) massive and polycrystalline aggregates (Figs. $4 \mathrm{e}, \mathrm{f}, 6$ ), frequently replacing fragments of fine-grained metamorphic rocks (mainly meta-pelites).

The disseminated crystals could not be recognised in routine petrographic observations. However, elemental mapping for Sr, P, and S performed during the EMPA study, combined with imaging of polished thin sections (Fig. 4) and of fresh fragments of these samples under scanning electron microscope (Fig. 5) reveals that APS minerals occur as idiomorphic pseudo-cubic single crystals which commonly present stepped faces (Fig. 5a), and they are surrounded by quartz and illite cements. These cements typically adapt to the shape of the pseudo-cubic idiomorphic APS crystals (Figs. 4d-f, 5b), indicating that the precipitation of the APS minerals clearly predates the formation of both types of cements. In some images, only the moulds of these cubic APS crystals can be recognised (Fig. 5b, c).

The isolated APS crystals locally coalesce to form polycrystalline aggregates (Fig. 4c-f). In the Benicasim section these APS crystals are closely related to the above described partially kaolinitised detrital micas and corroded feldspar grains. Kaolinite in samples from this section is usually intimately intergrown with APS minerals. In fact, it is possible to observe in the same sample APS crystals surrounded by kaolinite and APS polycrystalline aggregates growing on kaolinite particles (Fig. 4e).

As mentioned before, APS minerals can also be present as massive and polycrystalline aggregates that replace fragments of slate or phyllite (Fig. 6a, c, d). These replaced metamorphic rock fragments are commonly irregular and elongated and range in size between 20 and $300 \mu \mathrm{m}$ (Fig. 6a, d). Under the petrographic microscope these APS minerals occur as colourless aggregates with moderately positive relief and low birefringence. They are surrounded by detrital micas, which are commonly deformed and adapt to the shape of the rock fragments (Fig. 6a, c). Patches of iron oxide are closely intergrown with the APS minerals in some of these replaced fragments. The iron oxides most probably correspond to pseudomorphs after pyrite, as evidenced by the presence of frequent cubic shapes (Fig. 6d). The inner part of each aggregate shows a massive texture, whilst the external part is formed by more idiomorphic and well defined crystals (Fig. 6b), which compare in size to the above described disseminated APS minerals. Late quartz cements adapt to the idiomorphic morphologies of these crystals from the external part of the replaced rock fragments (Fig. 6d). Accordingly, the replacement took place in early stages, prior to the compaction of the sediments, and to the formation of the quartz cements. 

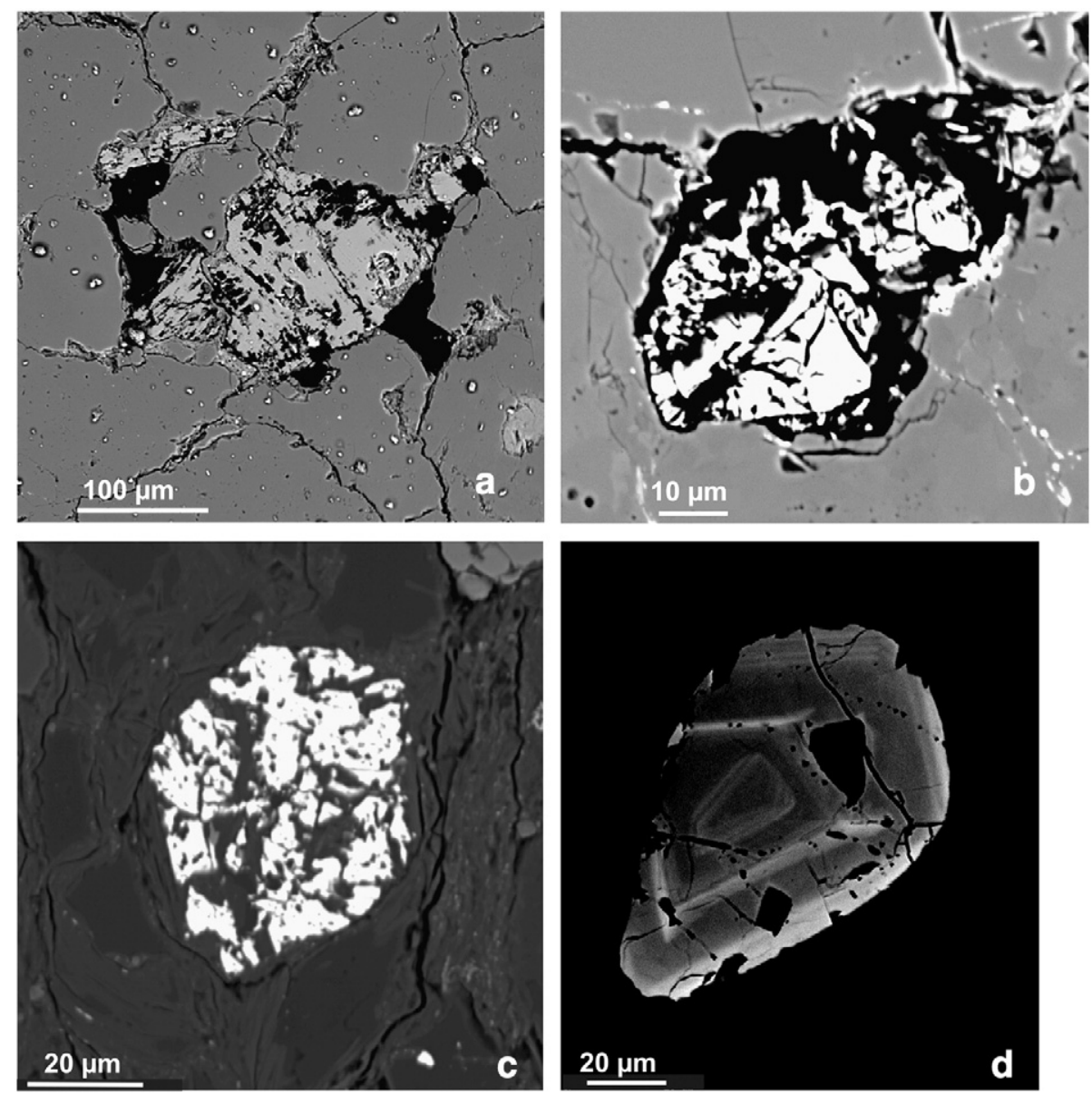


apatite (c), and zircons (d) typically show concentric zoning.

\subsubsection{Chemical composition and XRD characterisation}

Selected EMPA of APS minerals from the different cross-section are presented in Table 1 . The analytical data indicate a rather homogeneous composition along the different parts of the basin. The APS minerals show limited substitution of $\mathrm{PO}_{4}^{3-}$ by $\mathrm{SO}_{4}^{2-}$, with $\mathrm{S} / \mathrm{P}$ ratios that deviate from the ideal $1: 1$ of the sulphate/phosphate end members, giving an average value of 0.43 , although they may range between 0.18 and 0.86 . The dominant divalent cations in 12-fold coordination are $\mathrm{Sr}^{2+}$ and $\mathrm{Ca}^{2+}$ in an approximate ratio of 3:1. However, the sum of $\mathrm{Sr}+\mathrm{Ca}$ in most analyses ranges between 0.82 and 0.91 , being the remaining positions occupied by $\mathrm{Ce}^{3+}, \mathrm{La}^{3+}$ and minor proportions of other LREE. The plot of the analyses shown in Fig. 7 for the APS minerals falls within the field of solid solutions among woodhouseite, svanbergite, crandallite and goyazite end members.

In addition, the smallest disseminated APS crystals $(<3 \mu \mathrm{m})$ show a rather homogeneous composition, whilst concentric zoning is a common feature within the larger ones ( 3 to $6 \mu \mathrm{m}$ ). In some cases, the core of these zoned crystals is enriched in heavy elements like La and Ce (light coloured cores in Fig. 4b, d). However, the shapes of these inner cores are not pseudo-cubic, in contrast with the external shapes (Fig. 4e, f). A systematic contamination with $\mathrm{Si}$, Mg and Fe, and an excess of Al have been observed on the EMPA of the disseminated crystals of APS minerals, even when the spot size used was reduced to $1 \mu \mathrm{m}$.

The APS minerals were also detected on XRD traces, although it was difficult to discriminate their peaks from the background in bulk powdered samples, due to the low absolute contents. Runs performed on concentrates of the $<2 \mu \mathrm{m}$ fraction obtained by sedimentation yielded much better defined peaks (Fig. 8). According to the A.S.T.M. files, diffraction patterns of woodhouseite, svanbergite, crandallite and goyazite are very similar, differing only in relative intensities and in the presence of minor peaks. The $d$ spacings and relative intensities do not match exactly with any of the above mentioned end-members. The reflections at 4.88 and $2.97 \AA$ are clearly split, and there is a shoulder on the low-angle side of the peak at $5.66 \AA$. These features are in good agreement with the compositional data, also pointing to a solid solution among the four end-members.

No absolute quantification data are available for these mineral phases, but they are more abundant in samples from the Cañizar Formation, since they are more frequently recognised in routine petrographic analysis (larger modal content) and show greater intensity peaks in the XRD patterns.

\section{Discussion}

The petrographic and mineralogical features described for the siliciclastic rocks of continental origin in the Early-Middle Triassic units of the SE Iberian Range are very similar to those found in other areas like the Jura Basin, France (Lucas and Ataman, 1968), the British Isles (Jeans, 2006), the Betic Cordilleras, Spain (Ruiz Cruz and Andreo, 1996) and in previous studies within the Iberian Range (e.g., Marfil et al., 1996), except for the consistent presence of APS minerals in all the sections studied.

\subsection{Physical-chemical regime of the APS-bearing mineral association}

The APS minerals occur intimately intergrown with both kaolinite and hematite (patches of iron oxide), thus indicating a co-genetic relationship (Figs. 4a, 6d). Textural relationships indicate that these phases formed 




$100 \mu \mathrm{m}$



$50 \mu \mathrm{m}$

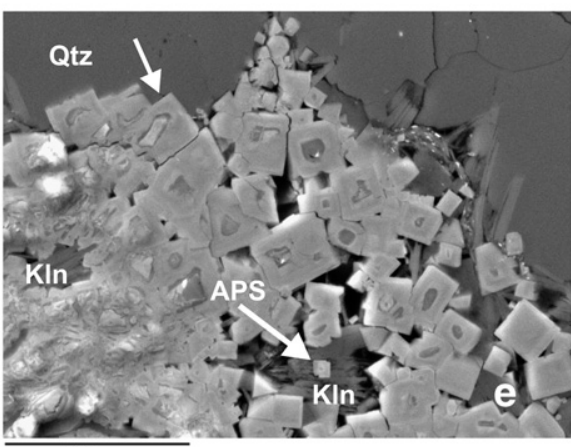

$20 \mu \mathrm{m}$

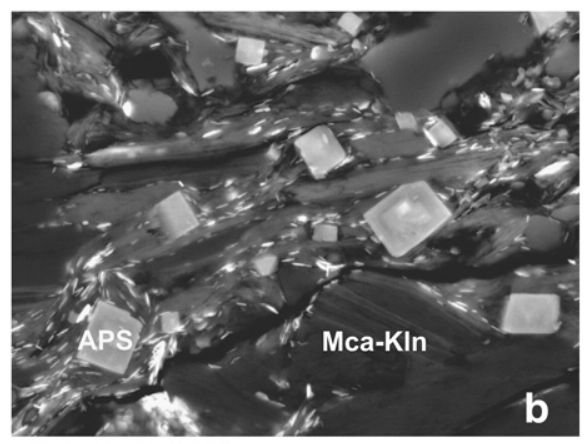

$10 \mu \mathrm{m}$

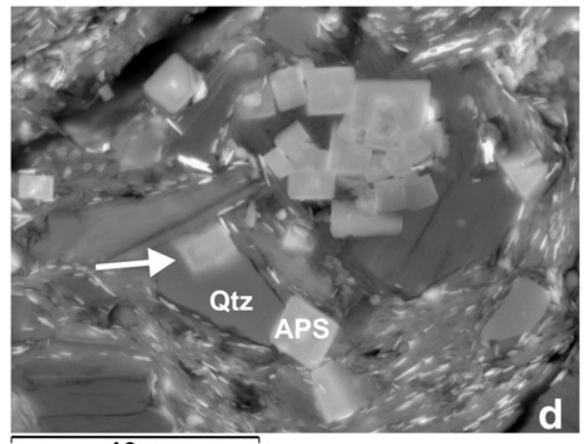

$10 \mu \mathrm{m}$

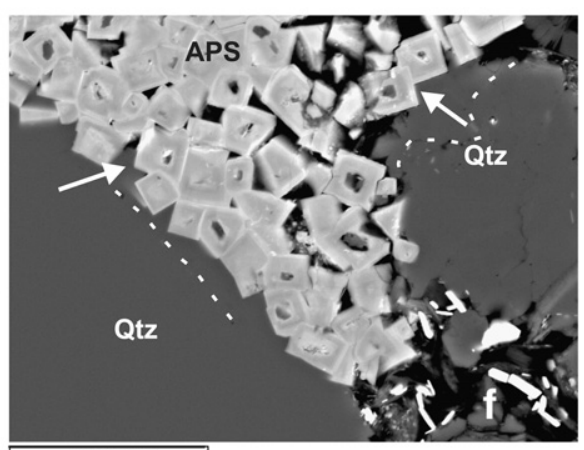

$20 \mu \mathrm{m}$

Fig. 4. Detailed images obtained on polished thin sections of different samples during the BSEM-EMPA study. a) Large detrital mica plate partially replaced by kaolinite. Note the fan-shaped edge formed by mica-kaolinite (Mca-kln) stacks. The presence of quartz (Qtz) grains and cements, haematite (Hem) coatings and isolated APS crystals is also indicated. b) Detailed image of isolated APS crystals within a clay matrix, closely associated with the mica-kaolinite stacks. Note that APS crystals show concentric zoning. c) Isolated APS idiomorphic crystals and aggregates (marked by arrows) embedded by the clay matrix. Note the booklets of dickite (D) with no preferred orientation. d) Detailed image of the area enclosed by the white frame on the previous picture, showing a polycrystalline aggregate of APS. The white arrow points to an isolated idiomorphic APS crystal surrounded by quartz cement. e) Polycrystalline aggregate of APS minerals around kaolinite (kln) in the upper half of the picture, and kaolinite nucleating around an APS tiny crystal in the lower half, thus indicating that both phases precipitated coevally. Note that many APS crystals show an irregular inner core. White arrows show the position of idiomorphic APS crystals surrounded by late quartz cements. f) Detail of APS crystals surrounded by late quartz cements (pointed by arrows). The limit between quartz grain and quartz cement is indicated by a dashed line.

after the partial or complete destabilisation of pre-existing minerals, as evidenced by the replacement of slate fragments by APS minerals and hematite (Fig. 6) and by the close association of the disseminated APS crystals and kaolinite with altered detrital mica plates (Fig. 4). It is therefore necessary to establish suitable conditions of formation for this mineral assemblage.
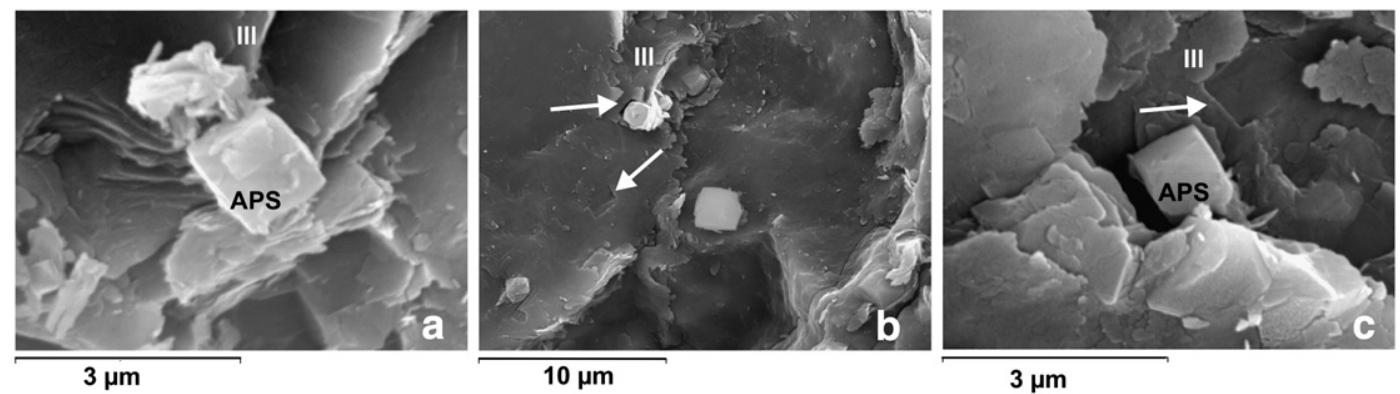

Fig. 5. SEM images on the fresh surface of fractured chips of sample CGA-11, a) Isolated idiomorphic (pseudocubic) APS crystal with stepped faces. b) Illite cements adapt to the shape of a tiny pseudocubic APS crystal (higher white arrow). Sometimes only the moulds of those idiomorphic crystals (lower arrow) defined by the illite (IIl) can be recognised. c) Pseudocubic APS crystal and another detail of illite cement adapted to the shape of a pre-existing APS idiomorphic crystal. Only the mould is visible (marked by a white arrow). 

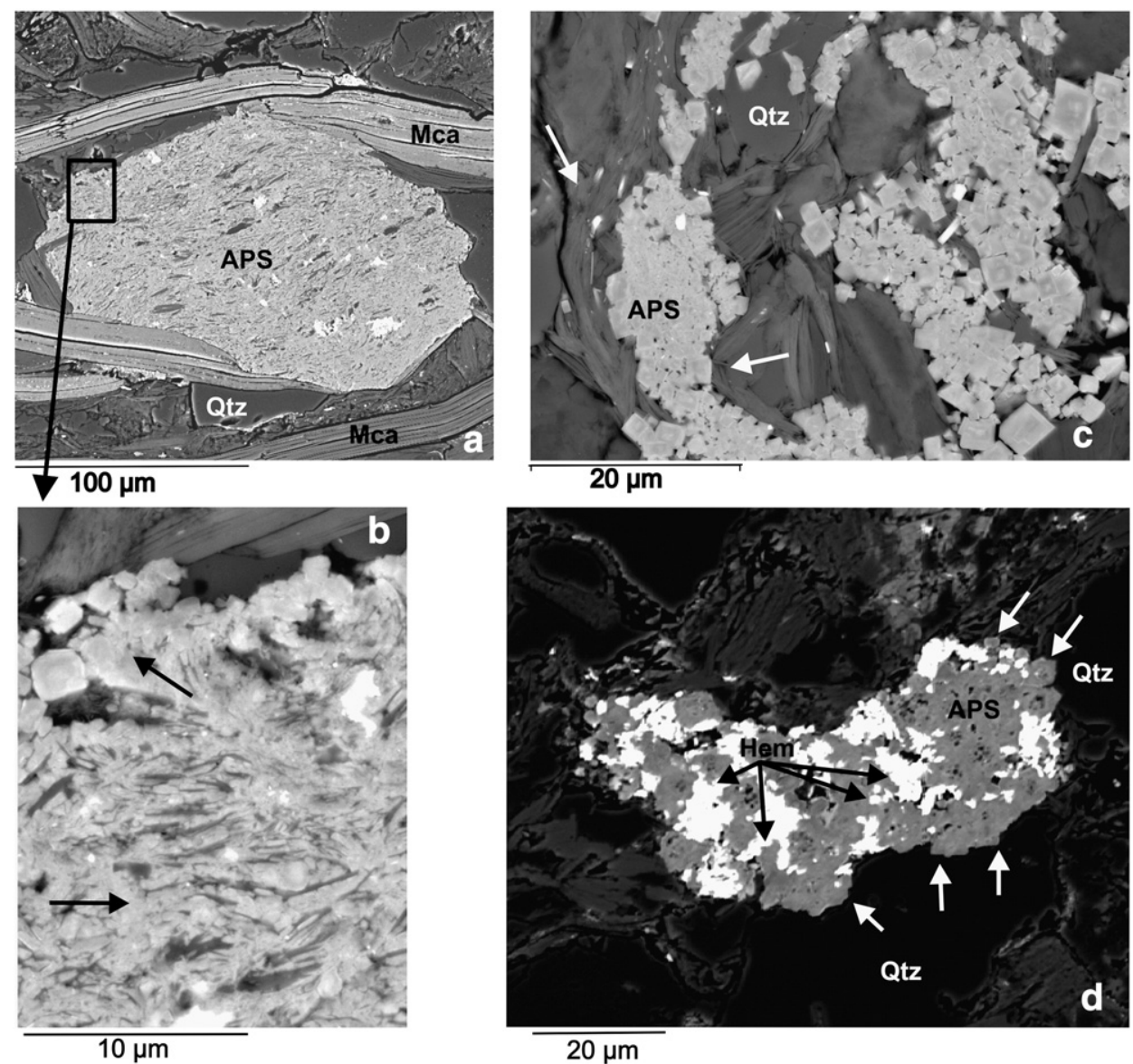

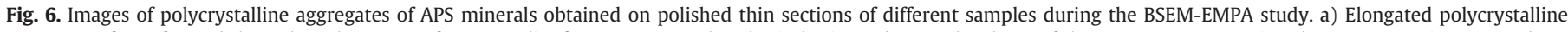

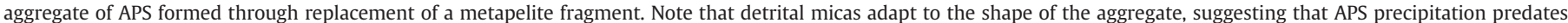

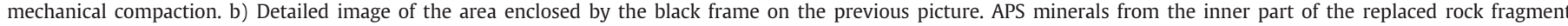

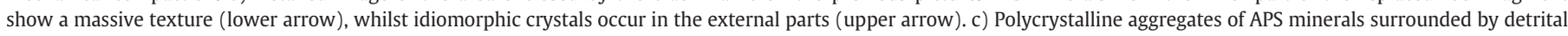

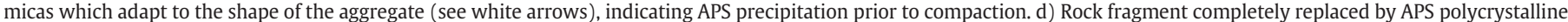

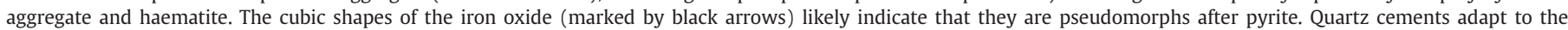
pseudocubic shapes of the APS crystals (marked by white arrows), clearly indicating that APS precipitation predates the formation of quartz (Q) cements.

The APS minerals show a rather homogenous composition (solid solutions among woodhouseite, svanbergite, crandallite and goyazite end members) in all the studied sections, and they have been found in sandstones, limestone and mudstone samples. Textural features like the idiomorphic character of the APS crystals and the presence of abundant stepped-faces observed during the SEM study in the small disseminated crystals (Fig. 4a-c), together with the replacing character of the APS mineral aggregates allow discard of detrital origin for these minerals. The presence of the stepped-faces and the extremely small and homogeneous size ( 0.7 to $5 \mu \mathrm{m}$ ) of the crystals point to a high nucleation rate during precipitation, which presumably took place over a short period of time. APS minerals form in conditions of high activity of $\mathrm{PO}_{4}^{3-}$ ions, high oxygen potential and relatively low $\mathrm{pH}$ values (Vieillard et al., 1979; Stoffregen and Alpers, 1987; Spötl, 1990). There are no thermodynamic data for APS minerals at any temperature, although Gaboreau and Vieillard (2004) presented a method to estimate Gibbs free energy of these phases. In a study of APS minerals associated with proterozoic uranium deposits in the Northern Territories (Australia), Gaboreau et al. (2005) plotted the stability domains calculated for svanbergite, goyazite and florencite end members in a $\log \left[\mathrm{Sr}^{2+} / \mathrm{Ce}^{3+}\right]$ vs $\mathrm{pH}$ for different values of $f\left(\mathrm{O}_{2}\right)$. They concluded that the stability of these minerals is highly sensitive to $\mathrm{pH}$ and showed that svanbergite (the phosphate-sulphate member) is the stable phase at low pH and relatively oxidising conditions. Such acidic and oxidising conditions can be recognised in our study and would therefore explain the occurrence of the Sr-rich aluminium phosphate-sulphate minerals.
Kaolinite frequently replaces corroded feldspars (Fig. 3a) and detrital mica plates (Fig. 4a), suggesting that it formed through weathering reactions (hydrolysis) of these phases under the above mentioned acidic conditions (e.g., Hurst and Irwin, 1982; Bjørlykke, 1998). This is a rather widespread process in continental sandstones, such as those characteristic of the Permian-Triassic sequences in the Betic Cordilleras (Ruiz Cruz and Andreo, 1996) and the SE Iberian Range (Arribas, 1987; de la Cruz et al., 1987; Martín-Martín et al., 2007).

The presence of frequent intergrowths of APS minerals and haematite patches in the replaced metapelite fragments can be regarded as indirect evidence of sulphide alteration. Moreover, many sandstone layers from the Benicasim section show abundant moulds of small and highly oxidised idiomorphic pyrite crystals. Pyrite oxidation reactions like $2 \mathrm{FeS}_{2}+7.5 \mathrm{O}_{2}+4 \mathrm{H}_{2} \mathrm{O} \rightarrow \mathrm{Fe}_{2} \mathrm{O}_{3}+4 \mathrm{H}_{2} \mathrm{SO}_{4}$, probably contributed to lower the $\mathrm{pH}$, at least locally (Fig. 6a, d).

As discussed below, these acidic conditions would also explain the partially corroded detrital phosphate (apatite and monazite) grains detected during the petrographic study, which likely provided $\mathrm{P}, \mathrm{Ca}$ and LREE for the precipitation of the APS minerals.

\subsection{Timing of the APS mineral formation}

Once the conditions of formation of the APS minerals were established, we must discuss whether they precipitated shortly after the sedimentation (sin-sedimentary or early diagenetic origin) or in a later episode (late diagenetic or hydrothermal origin). 
Table 1

EMPA of APS minerals of selected samples from the Gátova (Gat), Talayuelas (Tal) and Benicasim (Ben) cross sections. The cationic contents presented in the lower half of the table were calculated on the basis of 11 oxygen atoms.

\begin{tabular}{|c|c|c|c|c|c|c|c|c|c|}
\hline Sample & Gat 1 & Gat 3 & Gat 17 & Tal 11 & Tal 13 & Tal 230 & Ben 16 & Ben 17 & Ben 20 \\
\hline $\mathrm{SiO}_{2}$ & 0.53 & 4.93 & 3.62 & 0 & 0.04 & 0.11 & 0.00 & 0.28 & 0.00 \\
\hline $\mathrm{P}_{2} \mathrm{O}_{5}$ & 20.35 & 21.98 & 23.65 & 23.05 & 21.74 & 23.19 & 24.07 & 23.35 & 25.18 \\
\hline $\mathrm{SO}_{3}$ & 10.72 & 7.59 & 8.73 & 7.98 & 8.11 & 7.82 & 8.11 & 7.73 & 6.99 \\
\hline $\mathrm{SrO}$ & 10.13 & 10.69 & 11.01 & 12.09 & 12.19 & 13.20 & 12.12 & 12.46 & 13.61 \\
\hline $\mathrm{Al}_{2} \mathrm{O}_{3}$ & 35.66 & 35.91 & 38.38 & 34.78 & 33.22 & 35.63 & 37.36 & 35.40 & 36.42 \\
\hline $\mathrm{FeO}$ & 1.40 & 0.98 & 1.07 & 0.64 & 0.53 & 0.70 & 0.22 & 0.43 & 0.18 \\
\hline $\mathrm{MnO}$ & 0.00 & 0.00 & 0.00 & 0.10 & 0.04 & 0.02 & 0.01 & 0.01 & 0.00 \\
\hline $\mathrm{MgO}$ & 0.08 & 0.25 & 0.22 & 0.09 & 0.08 & 0.06 & 0.03 & 0.04 & 0.00 \\
\hline $\mathrm{BaO}$ & 0.83 & 0.40 & 0.39 & 0.36 & 0.28 & 0.55 & 0.12 & 0.10 & 0.11 \\
\hline $\mathrm{CaO}$ & 3.97 & 4.05 & 4.53 & 3.70 & 3.62 & 3.00 & 4.35 & 4.18 & 4.05 \\
\hline $\mathrm{Na}_{2} \mathrm{O}$ & 0.21 & 0.04 & 0.12 & 0.01 & 0.00 & 0.02 & 0.06 & 0.17 & 0.00 \\
\hline $\mathrm{K}_{2} \mathrm{O}$ & 0.39 & 0.59 & 0.33 & 0.05 & 0.10 & 0.15 & 0.06 & 0.10 & 0.04 \\
\hline $\mathrm{La}_{2} \mathrm{O}_{3}$ & 0.84 & 0.32 & 0.39 & 0.33 & 0.57 & 0.54 & 0.34 & 0.34 & 0.27 \\
\hline $\mathrm{Ce}_{2} \mathrm{O}_{3}$ & 1.05 & 0.82 & 0.74 & 1.62 & 1.45 & 1.52 & 0.66 & 0.56 & 0.71 \\
\hline $\mathrm{Nd}_{2} \mathrm{O}_{3}$ & 0.78 & 0.37 & 0.35 & 0.46 & 0.59 & 0.50 & 0.36 & 0.33 & 0.31 \\
\hline $\mathrm{F}$ & 0.74 & 0.50 & 0.66 & 0.50 & 0.34 & 0.48 & 0.75 & 0.80 & 0.64 \\
\hline Total & 87.68 & 89.42 & 94.19 & 85.75 & 82.89 & 87.47 & 88.60 & 86.27 & 88.51 \\
\hline $\mathrm{Si}$ & 0.04 & 0.36 & 0.25 & 0.00 & 0.00 & 0.01 & 0.00 & 0.02 & 0.00 \\
\hline $\mathrm{P}$ & 1.29 & 1.35 & 1.37 & 1.50 & 1.47 & 1.49 & 1.49 & 1.49 & 1.58 \\
\hline$S$ & 0.60 & 0.41 & 0.45 & 0.46 & 0.48 & 0.44 & 0.44 & 0.44 & 0.39 \\
\hline $\mathrm{Sr}$ & 0.44 & 0.45 & 0.44 & 0.54 & 0.57 & 0.58 & 0.51 & 0.55 & 0.58 \\
\hline $\mathrm{Al}$ & 3.14 & 3.07 & 3.10 & 3.15 & 3.13 & 3.18 & 3.22 & 3.16 & 3.18 \\
\hline $\mathrm{Cr}$ & 0.00 & 0.00 & 0.00 & 0.00 & 0.00 & 0.00 & 0.00 & 0.00 & 0.00 \\
\hline $\mathrm{Fe}$ & 0.09 & 0.06 & 0.06 & 0.04 & 0.04 & 0.04 & 0.01 & 0.03 & 0.01 \\
\hline $\mathrm{Mg}$ & 0.01 & 0.03 & 0.02 & 0.01 & 0.01 & 0.01 & 0.00 & 0.00 & 0.00 \\
\hline $\mathrm{Ba}$ & 0.02 & 0.01 & 0.01 & 0.01 & 0.01 & 0.02 & 0.00 & 0.00 & 0.00 \\
\hline $\mathrm{Ca}$ & 0.31 & 0.31 & 0.33 & 0.30 & 0.31 & 0.24 & 0.34 & 0.33 & 0.32 \\
\hline $\mathrm{Na}$ & 0.02 & 0.00 & 0.01 & 0.00 & 0.00 & 0.00 & 0.00 & 0.01 & 0.00 \\
\hline $\mathrm{K}$ & 0.04 & 0.05 & 0.03 & 0.00 & 0.01 & 0.01 & 0.01 & 0.01 & 0.00 \\
\hline La & 0.02 & 0.01 & 0.01 & 0.01 & 0.02 & 0.01 & 0.01 & 0.01 & 0.01 \\
\hline $\mathrm{Ce}$ & 0.03 & 0.02 & 0.02 & 0.05 & 0.04 & 0.04 & 0.02 & 0.02 & 0.02 \\
\hline $\mathrm{Nd}$ & 0.02 & 0.01 & 0.01 & 0.01 & 0.02 & 0.01 & 0.01 & 0.01 & 0.01 \\
\hline $\mathrm{F}$ & 0.17 & 0.12 & 0.14 & 0.12 & 0.09 & 0.12 & 0.17 & 0.19 & 0.15 \\
\hline
\end{tabular}

Textural relationships indicate that the precipitation of the APS minerals predates the formation of illite and quartz cements. In fact, both types of cements adapt to the shape of idiomorphic APS crystals (Figs. 4d-f, 5b, c, 6d). In addition, large detrital micas adapt to the shape of the metapelite rock fragments replaced by polycrystalline aggregates of APS minerals (Fig. 6a, c), suggesting that the mica plates were deformed during compaction. The inner part of each aggregate shows a massive texture, whilst the external part is formed by more idiomorphic and well defined crystals (Fig. 6b), which presumably had left space to develop. All of these features point to an early diagenetic stage for the replacement, which clearly took place prior to compaction of the sediment. There are some indirect evidences that also support the early nature of the APS minerals. As described before, kaolinite and APS minerals from the Benicasim section are intimately intergrown (Fig. 4a, e), thus indicating that both phases precipitated simultaneously. Mica replacement by kaolinite (and therefore the coeval precipitation of APS minerals) also took place prior to compaction, during the earliest stages after sedimentation, as revealed by the fan-shaped terminations of the replaced mica plates (Fig. 4a), since there was left space to occupy open pores within the sandstone grains. This early character of the kaolinite replacement in that area was previously noticed by Martín-Martín et al. (2007), who reported also extensive dickitisation of the kaolinite during late diagenesis, followed by precipitation of quartz and illite cements.

In addition, the APS minerals are systematically present in both the Cañizar and Eslida Formations along the whole study area, in cross-sections separated by large distances (see Fig. 2). There is no field evidence for hydrothermal mineralisation or alteration in the study area on a regional scale, although an important thermal resetting took place during the break-up of Pangea, in Late Triassic-Early Jurassic times in the Iberian Peninsula (Juez-Larré and Ter Voorde, 2009), and there are some local hydrothermal manifestations in the proximity of large faults in the study area (Benito et al., 2011). Moreover, the underlying Alcotas Formation is devoid of APS minerals, conversely to what we might expect if precipitation from rising hydrothermal fluids occurred. Therefore, there is a clear stratigraphic control on the occurrence of the APS minerals and the hydrothermal origin can be ruled out.

We can argue that the formation of APS minerals occurred shortly after the sedimentation, and most probably was related to the circulation of acidic meteoric water, since low $\mathrm{pH}$ environments and oxidising conditions at shallow depths are a common feature to most APS occurrences in different geologic settings (Dill, 2001). This is in good agreement with the origin proposed by Spötl (1990), Novak et al. (1997) and Pe-Piper and Dolansky (2005) for APS minerals of similar chemical composition (compound phosphate-sulphate) in continental sandstones in Austrian Alps, northern Bohemia, and Nova Scotia (Canada), respectively.

\subsection{Sources of $P, S$ and $S r$}

Once the timing and conditions of formation of the APS minerals were established, we need to find potential sources of specific elements in these minerals (i.e., $\mathrm{P}, \mathrm{Sr}$, and S) that should be available and ready to combine under the conditions suitable for the precipitation of the APS minerals.

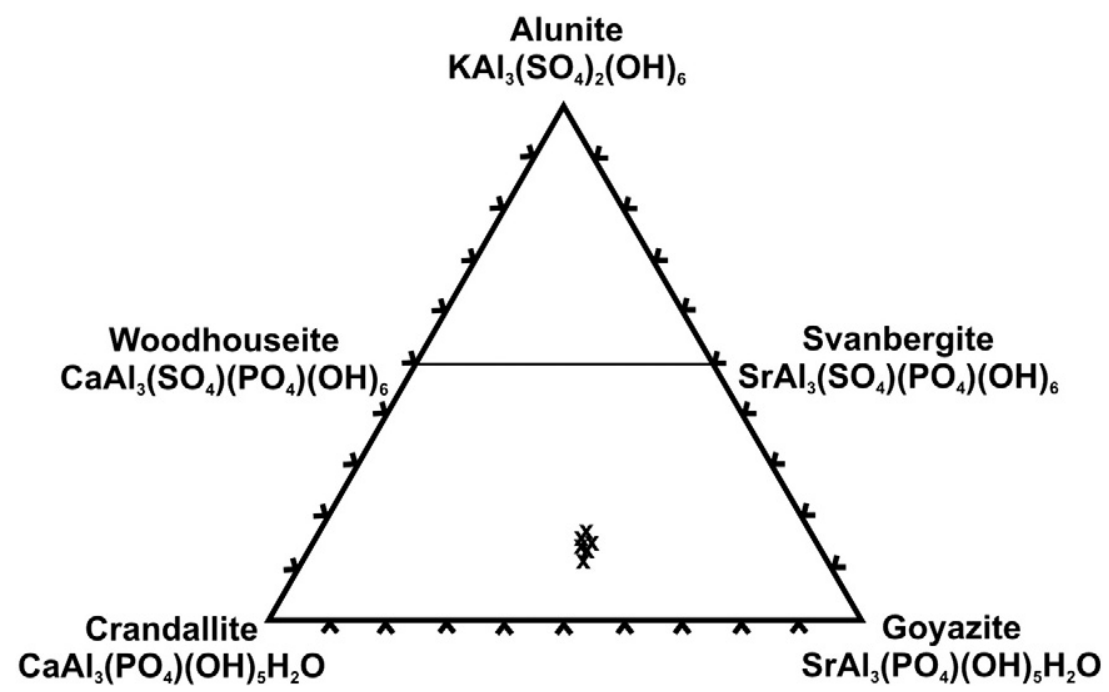

Fig. 7. Plot of the composition of the APS minerals determined by EMPA. 


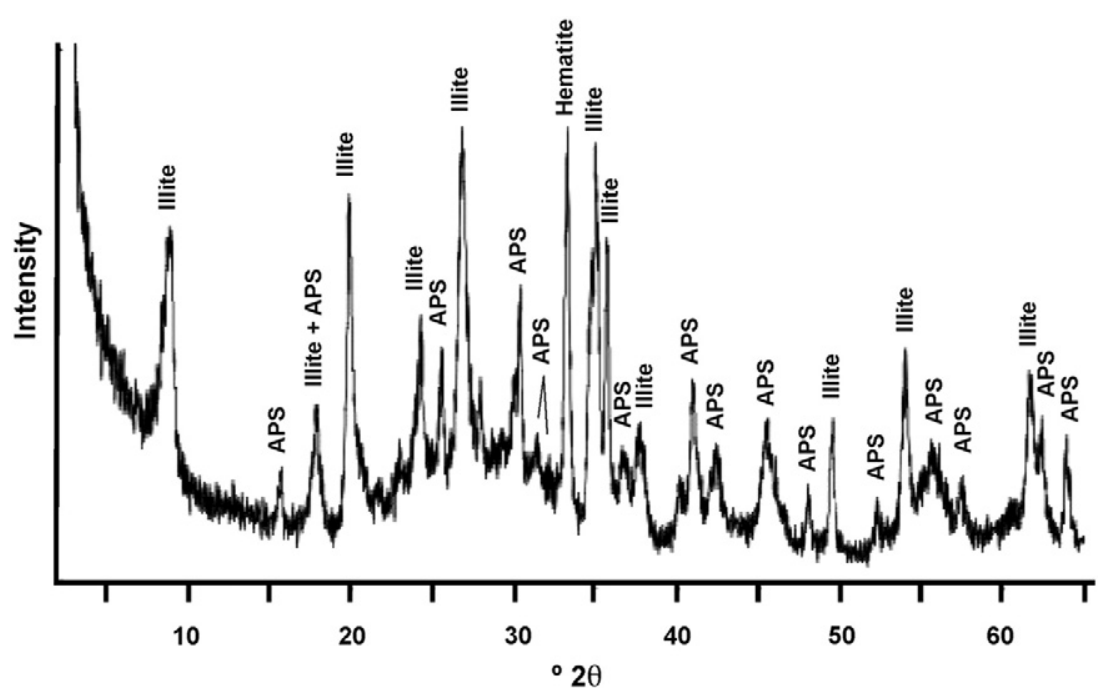

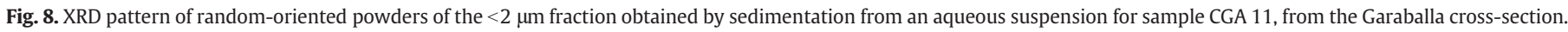

The presence of APS minerals in most samples analysed from the Cañizar and Eslida Formations implies an important enrichment in phosphorous content compared with the samples from the Alcotas Formation. Corroded detrital xenotime and apatite crystals observed in many samples suggest that phosphorus most probably derives from the dissolution of these phosphates. These phases are rather insoluble in alkaline conditions, but dissolve readily if $\mathrm{pH}$ values are lowered, especially apatite (Guidry and Mackenzie, 2003; Le Roux et al., 2006). This is the source for phosphorous found in other APS occurrences associated with siltstones and sandstones (Spötl, 1990; Pe-Piper and Dolansky, 2005). Thus, acidic conditions would have favoured the dissolution of the detrital phosphates prior to the precipitation of the APS minerals.

Phosphorous might also derive from air-fall volcanic ash. Different studies relate the formation of APS minerals to dissolution of volcanic glass in acidic conditions (Tan, 1984; Brownfield et al., 1986; Tripplehorn and Bohor, 1986; Tripplehorn and Finkelman, 1990; Rao and Walsh, 1997). Tripplehorn et al. (1991) found an alumino-phosphate (crandallite?) within a suite of authigenic minerals in an upper Palaeocene coal bed of the Powder River Basin (Wyoming), associated with anomalous concentrations of $\mathrm{Zr}, \mathrm{Ba}, \mathrm{Nb}, \mathrm{Sr}$ and $\mathrm{P}_{2} \mathrm{O}_{5}$. They related the formation of these secondary minerals to dissolution of volcanic glass in acidic conditions and re-precipitation of chemically leached labile components of the original ash material. In fact, Sr-rich alumino-phosphate minerals are frequently reported in volcanoclastic tonsteins associated with coals (Brownfield et al., 1986; Tripplehorn and Bohor, 1986). A similar mechanism has been recently proposed by Dill et al. (2011) to explain the formation of APS minerals in fine-grained sediments of the K/P boundary at the El Kef region (Tunisia). There is evidence of volcanic activity within the Iberian Range in the underlying and overlying units. Thus, tuffaceous rocks related to a magmatic episode at the Buntsandstein-Muschelkalk boundary in the western part of the basin (Marfil et al., 1998) and several layers of subvolcanic rocks near the top of the underlying Alcotas Formation in the study area (Lago et al., 2012) have been reported. We found no remains of this volcanic aerosol external input, like volcanic glass or cinerite layers within the sedimentary rock sequence, or the presence of elongated zircon crystals. However, this hypothesis cannot be discarded, because according to Tripplehorn and Finkelman (1990), nothing at all of the original ash or alteration products may be left after intense leaching.

An alternative source of phosphorus would be the alteration of phosphatic fossils, through the dissolution of bones. In a study of phosphate cemented-sandstone concretions, Thiry et al. (2006) concluded that phosphorous in collophane probably derived from the dissolution of bones in an acidic soil environment, with subsequent precipitation under $\mathrm{pH}$ control at the mixing zone of down-moving soil-water with calcite-saturated ground water. Sandstones, siltstones and mudstones along the whole stratigraphic cross-section are devoid of phosphatic fossils or moulds and only a few plant remains and fossil tracks have been identified. However, the contribution of biogenic phosphorus cannot be discarded if phosphatic fossils were completely dissolved. In any case, they do not appear to be the main source of phosphorus. Finally, we can rule out an origin related to weathering of marine phosphorites, since Permian-Triassic sedimentary rocks in the study area clearly correspond to continental fluvial systems and that type of deposit has never been described in the SE Iberian Range.

Concerning the sulphur contained in the APS minerals, it probably derives from the aforementioned destabilisation of pyrite, which would enhance acidification and eventually would result in the formation of the iron oxide patches that frequently occur intimately intergrown with the polycrystalline aggregates of APS.

The source for strontium is more difficult to determine. No Sr has been detected in microprobe analyses performed on feldspar or apatite detrital grains, which would be the most likely host-phases for this chemical element. Therefore, the high $\mathrm{Sr}$ contents needed to explain the precipitation of the APS minerals are apparently not related to dissolution of pre-existing minerals. Strontium might derive from diagenetic remobilisation of the overlying dolomites of the Muschelkalk facies. Nevertheless, it is difficult to explain how this remobilised strontium might reach the Cañizar Formation in sections like Gátova, where the fluids should circulate through more than one hundred metres of alternating impermeable lutites and siltstones of the Eslida Formation. In addition, as stated before, the formation of the APS minerals took place shortly after deposition, through the action of low $\mathrm{pH}$ meteoric ground waters, well before the marine influence that prevailed during the deposition of the Muschelkalk carbonates. Therefore, the source of strontium for the formation of APS minerals remains unclear and we must consider the possibility of an external input. The above mentioned air-fall volcanic ash might be a likely source of strontium, as well as sulphur, and probably a complementary source of phosphorous in our samples, although this is not currently supported by any independent field or petrographic criteria.

\subsection{APS minerals and the recovery of life during Early-Middle Triassic}

The recognition of the APS minerals in both the Cañizar and Eslida Formations is very important, since they can provide useful information on the physical-chemical conditions (Eh, pH) (Stoffregen and Alpers, 
1987; Dill, 2001) that prevailed during the recovery of life in EarlyMiddle Triassic times, after the biotic crisis at end of the Palaeozoic. According to Benito et al. (2005) and De la Horra et al. (2008), the detailed study of palaeosols along the underlying Alcotas Formation reveals a progressive change towards more oxidising and acidic conditions within a semiarid climate during the Middle Permian. In the Triassic, López-Gómez et al. (2012) describe some aeolian reworking within the Cañizar Formation and equivalent units to Cañizar and Eslida Formations have been interpreted as aeolian sediments in the Aragonian branch of the Iberian Range (Soria et al., 2011) and in the Catalonian Coastal Range (Marzo and Calvet, 1985). It is generally accepted that extremely arid conditions prevailed in Iberia during Early Triassic times, as in many areas of west Europe (Bourquin et al., 2011).

The APS minerals can be considered as indicators of sustained acidic and oxidising conditions in the meteoric waters during this period. Such conditions would certainly contribute to the delay of life recovery. Alternatively, these conditions might result from the repeated effect of several crises. Retallack et al. (2011) suggested that multiple Early Triassic greenhouse crises impeded recovery from Late Permian mass extinction. The levels containing APS minerals in these units could represent different stages, including one at the Scythian-Anisian boundary. With the data available none of these options, the sustained environmental damage or the multiple stage crises, can be ruled out. As mentioned before, the Cañizar Formation shows a relatively higher content of APS minerals than the Eslida Formation. In addition, Cañizar Formation is almost devoid of any fossil remain; except for some ichnites in the Benicasim section (Gand et al., 2010), incipient palaeosols (López-Gómez et al., 2012) and one palynological association (Doubinger et al., 1990), all of them were found near the top of the formation. However, the Eslida Formation represents a progressive change in the environmental conditions, leading to wider soil development and greater palaeontological content (Béthoux et al., 2009; Gand et al., 2010; López-Gómez et al., 2012), coinciding with the decrease in the APS minerals content.

\section{Concluding remarks}

An anomalous concentration of Sr-rich APS minerals has been recognised in fluvial mudstones, siltstones and sandstones from the Cañizar and Eslida Formations (Early-Middle Triassic), in the SE Iberian Range. The mineralogical study shows that the formation of the APS minerals took place shortly after sedimentation, during a period of increased weathering (with low $\mathrm{pH}$ and oxidising conditions) compared with the conditions that prevailed during the sedimentation of the underlying Alcotas Formation.

The mechanism of formation of the APS minerals in these units includes an early stage in which acidic conditions promoted the partial dissolution of detrital xenotime, apatite, mica and feldspar. Meteoric solutions concentrated P, Ca and REE (released from detrital phosphates), $\mathrm{K}$ and $\mathrm{Al}$ (from feldspar and mica), $\mathrm{S}$ (partly coming from pyrite destabilisation), and $\mathrm{Sr}$ (most probably incorporated from an external source) at shallow depth shortly after sedimentation, leading to the precipitation of the APS minerals and to mica replacement by kaolinite.

The presence of the APS minerals in these rocks might have important implications in the context of the Early-Middle Triassic recovery of life, since they can be considered as evidence of acidic and oxidising conditions in this period, due to sustained environmental damage or to multiple stage crises. Additional work is needed in neighbouring PermianTriassic basins to investigate if equivalent units contain APS minerals as well, which would suggest widespread development of such environmental conditions.

\section{Acknowledgements}

This study was financially supported through projects CGL200728731-E, CGL2010-09503-E and CGL2011-24408. B. Galán-Abellán is currently enjoying a DAAD Grant at the Geologisches Institut, Bonn University, Germany. The authors gratefully acknowledge the staff of the Centro Nacional de Microscopía (Universidad Complutense de Madrid) for their help in the EMPA and SEM study. B. Soutullo is also thanked for technical assistance during the X-ray diffraction study. The manuscript was improved with comments and suggestions by two anonymous reviewers and by the editor.

\section{References}

Alonso-Azcárate, J., Arche, A., Barrenechea, J.F., López-Gómez, J., Luque, F.J., Rodas, M., 1997. Palaeogeographical significance of clay mineral assemblages in the Permian and Triassic sediments of the SE Iberian Ranges, eastern Spain. Palaeogeography, Palaeoclimatology, Palaeoecology 136, 309-330.

Arche, A., López-Gómez, J., 1996. Origin of the Permian-Triassic Iberian Basin, centraleastern Spain. Tectonophysics 266, 443-464.

Arche, A., López-Gómez, J., 1999. Tectonic and geomorphic controls on the fluvial styles of the Eslida Formation, Middle Triassic, Eastern Spain. Tectonophysics 315, 187-207.

Arche, A., López-Gómez, J., 2005. Sudden changes in fluvial style across the PermianTriassic boundary in the eastern Iberian Ranges, Spain: analysis of possible causes. Palaeogeography, Palaeoclimatology, Palaeoecology 229, 104-126.

Arche, A., López-Gómez, J., 2006. Late Permian-Early transition in Central and NE Spain: biotic and sedimentary characteristics. In: Lucas, S., Cassinis, G., Schneider, J. (Eds.), Non-Marine Permian Biostratigraphy and Biochronology: Geological Society of London, Special Publication, 265, pp. 261-280.

Arche, A., López-Gómez, J., Marzo, M., Vargas, H., 2004. The siliciclastic Permian-Triassic deposits in Central and Northeastern Iberian Peninsula (Iberian, Ebro and Catalan Basins): a proposal for correlation. Geologica Acta 2, 305-320.

Arribas, J., 1987. Origen y significado de los cementos en las areniscas de las facies Buntsandstein (Rama Aragonesa de la Cordillera Ibérica). Cuadernos de Geologia Iberica $11,535-556$.

Benito, M.I., De La Horra, R., Barrenechea, J.F., López-Gómez, J., Rodas, M., AlonsoAzcárate, J., Arche, A., Luque, F.J., 2005. Late Permian continental sediments in the SE Iberian Ranges, eastern Spain: petrological and mineralogical characteristics and palaeoenvironmental significance. Palaeogeography, Palaeoclimatology, Palaeoecology 229, 24-39.

Benito, M.I., De La Horra, R., Barrenechea, J.F., López-Gómez, J., Luque, F.J., Arche, A. 2011. Shallow burial dolomitisation of Middle-Upper Permian paleosols in an extensional tectonic context (SE Iberian Basin, Spain): controls on temperature of precipitation and source of fluids. Sedimentary Geology 237, 135-149.

Benton, M.J., 2003. When life nearly died. The Greatest Mass Extinction of All Time.Thames and Hudson, London (336 pp.)

Béthoux, O., De La Horra, R., Benito, M.I., Barrenechea, J.F., Galán, A.B., López-Gómez, J., 2009. A new triadotypomorphan insect from the Anisian (Middle Triassic), Buntsandstein facies, Spain. Journal of Iberian Geology 35, 177-182.

Bourquin, S., Durand, M., Diez, J.B., Broutin, J., Fluteau, F., 2007. The Permian-Triassic boundary and Early Triassic sedimentation in Western European basins: an overview. Journal of Iberian Geology 33, 221-236.

Bourquin, S., Bercovici, A., López-Gómez, J., Díez, J.B., Broutin, J., Ronchi, A., Durand, M., Arche, A., Linol, L., Amour, F., 2011. The Permian-Triassic transition and the onset of Mesozoic sedimentation at the northwestern peri-Tethyan domain scale: palaeogeographic maps and geodynamic implications. Palaeogeography, Palaeoclimatology, Palaeoecology 299, 265-280.

Brownfield, M.E., Affolter, R.H., Cathcart, J.D., Johnson, S.Y., Brownfield, I.K., Rice, C.A., 1986. Geologic setting and characterization of coals and the modes of occurrence of selected elements from the Franklin coal zone, Puget Group, John Henry No. 1 mine, King County, Washington, USA. International Journal of Coal Geology 63, 247-275.

Bjørlykke, K., 1998. Clay mineral diagenesis in sedimentary basins: a key to the prediction of rock properties. Examples from the North Sea Basin. Clay Minerals 33, $15-34$.

Clapham, M.E., Shen, S.Z., Bottjer, D.J., 2009. The double mass extinction revisited: reassessing the severity, selectivity, and paleobiogeographic pattern of the endGuadalupian biotic crisis (Middle-Late Permian). Paleobiology 35, 32-50.

Corsetti, F.A., Baud, A., Marenco, P.J., Richoz, S., 2005. Summary of Early Triassic carbon isotope records. Paleovol 4, 405-418.

De la Cruz, B., Marfil, R., De la Peña, J.A., Arribas, J., 1987. Procedencia y evolución diagenética de las areniscas permo-triásicas de la Cordillera Ibérica (Sierra de Albarracín-Boniches-Talayuelas, provincias de Teruel y cuenca). Cuadernos de Geologia Iberica 11, 493-514.

De La Horra, R., Benito, M.I., López-Gómez, J., Arche, A., Barrenechea, J.F., Luque, F.J., 2008. Palaeoenvironmental significance of Late Permian palaeosols in the SouthEastern Iberian Ranges, Spain. Sedimentology 55, 1849-1873.

De la Horra, R., Galán-Abellán, B., López-Gómez, J., Sheldon, N., Barrenechea, J.F., Luque, J., Arche, A., Benito, M.I., 2012. Paleoecological and paleoenvironmental changes during the continental Middle-Late Permian transition at the SE Iberian Ranges, Spain. Global and Planetary Changes 94-95, 46-61.

De Vicente, G., Vegas, R., Muñoz-Martín, A., Van Wees, J.D., Casas-Sáinz, A., Sopeña, A., Sánchez-Moya, Y., Arche, A., López-Gómez, J., Oláiz, A., Fernández-Lozano, J., 2009. Oblique strain partitioning and transpression on an inverted rift: the Castilian Branch of the Iberian Chain. Tectonophysics 470, 224-242.

Dill, H.G., 2001. The geology of aluminium phosphates and sulphates of the alunite group minerals: a review. Earth-Science Reviews 53, 35-93. 
Dill, H.G., Dorhmann, R., Kaufhold, S., Weber, B., 2011. Clay mineralogy and chemistry of fine-grained sediments. Environment analysis around the $\mathrm{K} / \mathrm{P}$ boundary at Sekarna/Kasserina island, Tunisia. Neues Jahrbuch für Mineralogie Abhandlungen $188,285-296$

Doubinger, J., López-Gómez, J., Arche, A., 1990. Pollen and spores from the Permian and Triassic sediments of the southeastern Iberian Ranges, Cueva de Hierro (Cuenca) to Chelva-Manzanera (Valencia-Teruel) region, Spain. Reviews of Paleobotany and Palynology 66, 25-45.

Durand, M., 2006. The problem of the transition from the Permian to the Triassic series in southeastern France: comparison with other Perithetyan regions. In: Lucas, S., Cassinis, G., Schneider, J. (Eds.), Non-Marine Permian Biostratigraphy and Biochronology: Geological Society of London, Special Publication, 265, pp. 281-296.

Dutrizac, J.E., Jambor, J.L., 2000. Jarosites and their application in hydrometallurgy. In: Alpers, C.N., Jambor, J.L., Nordstrom, D.K. (Eds.), Reviews in Mineralogy and Geochemistry: Mineralogical Society of America and Geochemical Society, 40, pp. 405-452.

Erwin, D.H., 1993. The great Paleozoic crisis. Columbia University Press, New York (327 pp.).

Erwin, D.H., 1994. The Permo-Triassic extinction. Nature 367, 231-236.

Erwin, D.H., 2006. Extinction. How Life on Earth Nearly Ended 250 Million Years Ago. Princenton University Press, Princenton, Oxford (296 pp.).

Erwin, D.H., Bowring, S.A., Yugan, J., 2002. End Permian mass extinction: a review. Geological Society of America Special Paper 356, 363-383.

Escudero-Mozo, M.J., Márquez, L., Martín-Chivelet, J., López-Gómez, J., 2012. Foraminíferos anisienses en la Fm Landete (facies Muschelkalk): Implicaciones biostratigráficas para la primera transgresión mesozoica en el SE de la Cordillera Ibérica. Geogaceta 51, 31-34.

Gaboreau, S., Vieillard, P., 2004. Prediction of Gibbs free energies of formation of minerals of the alunite supergroup. Geochimica et Cosmochimca Acta 68, 3307-3316

Gaboreau, S., Beaufort, D., Vieillard, P., Patrier, P., Bruneton, P., 2005. Aluminum phosphatesulfate minerals associated with Proterozoic unconformity-type uranium deposits in the East Alligator River Uranium Field, Northern Territories, Australia. The Canadian Mineralogist 43, 813-827.

Gaboreau, S., Cuney, M., Quirt, D., Beaufort, D., Patrier, P., Mathieu, R., 2007. Significance of aluminum phosphate-sulfate minerals associated with U unconformity-type deposits: the Athabasca basin, Canada. American Mineralogist 92, 267-280.

Galfetti, T., Bucher, H., Brayard, A., Hochuli, P.A., Weissert, H., Guodun, K., Atudorei, V. Guex, J., 2007. Late Early Triassic climate change: Insights from carbonate carbon isotopes, sedimentary evolution and ammonoid paleobiogeography. Palaeogeography, Palaeoclimatology, Palaeoecology 243, 394-411.

Gand, G., De La Horra, R., Galan-Abellan, B., López-Gómez, J., Barrenechea, J.F., Arche, A. Benito, M.I., 2010. New icnites from the Middle Triassic of the Iberian Ranges (Spain): paleoenvironmental and paleogeographical implications. Historical Biology $22,40-56$

Gorsky, V., Gusseva, E., Crasquin-Soleau, S., Broutin, J., 2003. Stratigraphic data of the Middle-Late Permian on Russian Platforms. Geobios 36, 533-558.

Guidry, M.W., Mackenzie, F.T., 2003. Experimental study of igneous and sedimentary apatite dissolution: control of $\mathrm{pH}$, distance from equilibrium, and temperature on dissolution rates. Geochimica et Cosmochimica Acta 67, 2949-2963.

Hallam, A., Wignall, P.B., 1997. Mass Extinctions and Their Aftermath. Oxford University Press, New York (319 pp.).

Hawthorne, F.C., Krivovichev, S.V., Burns, P.C., 2000. The crystal chemistry of sulfate minerals. In: Alpers, C.N., Jambor, J.L., Nordstrom, D.K. (Eds.), Reviews in Mineralogy and Geochemistry: Mineralogical Society of America and Geochemical Society, 40, pp. 1-101.

Hurst, A., Irwin, H., 1982. Geological modelling of clay diagenesis in sandstones. Clays and Clay Minerals 17, 5-22.

Jambor, J.L., 1999. Nomenclature of the alunite supergroup. The Canadian Mineralogist $37,1323-1341$.

Jeans, C.V., 2006. Clay mineralogy of the Permo-Triassic strata of the British Isles: onshore and offshore. Clay Minerals 41, 309-354.

Juez-Larré, J., Ter Voorde, M., 2009. Thermal impact of the break-up of Pangea on the Iberian Peninsula, assessed by thermochronological dating and numerical modeling. Tectonophysics 474, 200-213.

Khalaf, F.I., 1990. Diagenetic alunite in clastic sequences, Kuwait, Arabian Gulf. Sedimentology 37, 155-164.

Kisch, H.J., Árkai, P., Brime, C., 2004. On the calibration of the illite Kübler index (illite "crystallinity"). Schweizerische Mineralogische und Petrographische Mitteilungen 84, 323-331.

Krull, E.S., Retallack, G.J., Campbell, H.J., Lyon, G.L., 2000. $\delta^{13}$ Corg chemostratigraphy of the Permian-Triassic boundary in the Maitai Group, New Zealand: evidence for high-latitudinal methane release. New Zealand Journal of Geology and Geophysics 112, 21-32.

Krull, E.S., Retallack, G., 2000. $\delta^{13} \mathrm{C}$ profiles from paleosols across the Permian-Triassic boundary: evidence for methane release. GSA Bulletin 112, 1459-1472.

Le Roux, G., Laverret, L., Shotyk, W., 2006. Fate of calcite, apatite and feldspars in an ombrotrophic peat bog, Black Forest, Germany. Journal of the Geological Society 163, 641-646.

Lago, M., De la Horra, R., Ubide, T., Galé, C., Galán-Abellán, B., Barrenechea, J.F., LópezGómez, J., Benito, M.I., Arche, A., Alonso-Azcárate, J., Luque, F.J., Timmerman, M.J., 2012. First report of a Middle-Upper Permian magmatism in the SE Iberian Ranges: characterisation and comparison with coeval magmatisms in the western Tethys. Journal of Iberian Geology 38.

Lehrmann, D.J., Ramezani, J., Bowring, S.A., Martin, M.W., Montgomery, P., Enos, P., Payne, J.L., Orchard, M., Wang, H.-M., Wei, J., 2006. Timing of biotic recovery from the end-Permian extinction: geochronologic and biostratigraphic constraints from south China. Geology 34, 1053-1056.
López-Gómez, J., Arche, A., 1993. Sequence stratigraphy analysis and paleogeographic interpretation of the Buntsandstein and Muschelkalk facies (Permo-Triassic) in the SE Iberian Ranges, eastern Spain. Palaeogeography, Palaeoclimatology, Palaeoecology 103, 347-361.

López-Gómez, J., Arche, A., Pérez-López, A., 2002. Permian and Triassic. In: Gibbons, W. Moreno, T. (Eds.), Geology of Spain. Geological Society of London, pp. 185-212.

López-Gómez, J., Arche, A., Marzo, M., Durand, M., 2005. Stratigraphical and palaeogeographical significance of the continental sedimentary transition across the Permian-Triassic boundary in Spain. Palaeogeography, Palaeoclimatology, Palaeoecology 229, 3-23.

López-Gómez, J., Arche, A., De La Horra, R., Galán-Abellán, B., Barrenechea, J.F., 2011 Permian-Triassic continental rocks of the SE Iberina Ranges: architecture, tectonics and geochemical characteristics in the context of a rift basin. In: Arenas, C., Pomar, L., Colombo, F. (Eds.), Geo-Guías: Post Meeting Field trips 28th IAS Meeting, Zaragoza, 8 , pp. 11-43.

López-Gómez, J., Galán-Abellán, B., De la Horra, R., Barrenechea, J.F., Arche, A. Bourquin, S., Marzo, M., Durand, M., 2012. Sedimentary evolution of the continental Early-Middle Triassic Cañizar Formation (Central Spain): implications for life recovery after the Permian-Triassic crisis. Sedimentary Geology 249-250, 26-44.

Lucas, J., Ataman, G., 1968. Mineralogical and geochemical study of clay mineral transformations in the sedimentary Triassic Jura Basin (France). Clays and Clay Minerals $16,365-372$.

Marfil, R., Scherer, M., Turrero, M.J., 1996. Diagenetic processes influencing porosity in sandstones from the Triassic Buntsandstein of the Iberian Range, Spain. Sedimentary Geology 105, 203-219.

Marfil, R., Hall, A., García-Gil, S., Stamatakis, M.G., 1998. Petrology and geochemistry of diagenetically altered tuffaceous rocks from the Middle Triassic of Central Spain. Journal of Sedimentary Research 68, 391-403.

Márquez, L., López-Gómez, J., Trifonova, E., 1994. Datación (foraminíferos) y ambientes sedimentarios de la Formación Dolomías de Landete, Anisiense, Facies Muschelkalk, provincia de Cuenca. Boletin de la Real Sociedad Española de Historia Natural (Sección Geológica) 84, 1-4.

Martín-Martín, J.D., Gómez-Gras, D., Sanfeliu, T., Thiry, M., Ruiz-Cruz, M.D., Franco, F., 2007. Extensive dickitization of the Permo-Triassic fluvial sandstones from the eastern Iberian Range, Spain. Clays and Clay Minerals 55, 481-490.

Marzo, M., Calvet, F., 1985. El Triásico de los Catalánides. II Coloquio Estratigráfico y Paleogeográfico del Pérmico y Triásico de España. Institut d'estudis Ilerdencs, Lleida pp. $1-175$.

Metcalfe, I., Foster, C.B., Afonin, S.A., Nicoll, R.S., Mundil, R., Wang, X.F., Lucas, S.G., 2009 Stratigraphy, biostratigraphy and C-isotopes of the Permian-Triassic nonmarine sequence at Dalongkou and Lucaogou, Xinjiang Province, China. Journal of Asian Earth Sciences 36, 503-520.

Novak, F., Paulis, P., Moravec, B., 1997. Minerals of goyazite-svanbergite series and kemmlitzite from pyrope deposit Vestrev near Hostinne, Northern Bohemia. Bulletin of the Czech Geological Survey 72, 373-380.

Payne, J.L., Lehrmann, D.J., Wei, J., Orchard, M.J., Schrag, D.P., Knoll, A.H., 2004. Large perturbations of the carbon cycle during recovery from the end-Permian extinction. Science 305, 506-509.

Pe-Piper, G., Dolansky, L.M., 2005. Early diagenetic origin of Al phosphate-sulphate minerals (woodhouseite and crandallite series) in terrestrial sandstones, Nova Scotia, Canada. American Mineralogist 90, 1434-1441.

Pettijohn, F.J., 1975. Sedimentary Rocks. Harpercollins, New York.

Polyak, V.J., Güven, N., 1996. Alunite, natroalunite and hydrated halloysite in Carlsbad Cavern and Lechuguilla Cave, New Mexico. Clays and Clay Minerals 44 843-850.

Ramos, A., 1979. Estratigrafía y paleogeografía del Pérmico y Triásico al oeste de Molina de Aragón (Provincia de Guadalajara). Seminarios de Estratigrafía. Serie Monografías 6, 1-313.

Rao, P.D., Walsh, D.E., 1997. Nature and distribution of phosphorus minerals in Cook Inlet coals, Alaska. International Journal of Coal Geology 33, 19-42.

Rasmussen, B., 1996. Early-diagenetic REE-Phosphate minerals (florencite, gorceixite, crandallite, and xenotime) in marine sandstones: a major sink for oceanic phosphorus. American Journal of Science 296, 601-632.

Renne, P.R., Zichao, Zhang, Richards, M.A., Black, M.T., Basu, A.R., 1995. Synchrony and causal relations between Permian-Triassic boundary crises and Siberian flood volcanism. Science 269, 1413-1416.

Retallack, G.J., 1999. Postapocalyptic greenhouse paleoclimate revealed by earliest Triassic paleosols in the Sydney Basin, Australia. Geological Society of America Bulletin 111, 55-70.

Retallack, G.J., Sheldon, N.D., Carr, P.F., Fanning, M., Thompson, C.A., Williams, M.L., Jones, B.G., Hutton, A., 2011. Multiple Early Triassic greenhouse crises impeded recovery from Late Permian mass extinction. Palaeogeography, Palaeoclimatology, Palaeoecology 308, 233-251.

Ruiz Cruz, M.D., Andreo, B., 1996. Genesis and transformation of dickite in PermoTriassic sediments (Betic Cordilleras, Spain). Clay Minerals 31, 133-152.

Sánchez-Moya, Y., Sopeña, A., 2004. El rift mesozoico ibérico. In: Vera, J.A. (Ed.), Geología de España. IGME, Sociedad Geológica de España, Madrid, pp. 484-492.

Sopeña, A., López, J., Arche, A., Pérez-Arlucea, M., Ramos, A., Virgili, C., Hernando, S. 1988. Permian and Triassic rift basins of the Iberian Peninsula. In: Manspeizer, W. (Ed.), Triassic-Jurassic Rifting. : Developments in Geotectonics, 22. Elsevier, Amsterdam, pp. 757-786.

Soria, A.R., Liesa, C.L., Rodríguez-López, J.P., Meléndez, N., De Boer, P.L., Meléndez, A. 2011. An early Triassic evolving erg system. Palaeoclimate implications. Terra Nova 23, 76-84.

Spötl, C., 1990. Authigenic aluminium phosphate-sulphates in sandstones of the Mitterberg Formation, Northern Calcareous Alps, Austria. Sedimentology 37, 837-845. 
Stoffregen, R.E., Alpers, Ch.N., 1987. Woodhouseite and svanbergite in hydrothermal ore deposits: products of apatite destruction during advanced argillic alteration. The Canadian Mineralogist 25, 201-211.

Tan, K., 1984. Andosols. Van Nostrand-Reinhold, New York (418 pp.).

Thiry, M., Galbois, J., Schmitt, J.-M., 2006. Unusual phosphate concretions related to groundwater flow in a continental environment. Journal of Sedimentary Research $76,866-870$.

Tripplehorn, D., Bohor, B., 1986. Volcanic ash layers in coal: origin, distribution, composition, and significance. In: Vorres, K.S. (Ed.), Mineral Matter and Ash in Coal: American Chemical Society Symposium series, 301, pp. 90-98.

Tripplehorn, D., Finkelman, R.B., 1990. Replacement of glass shards by aluminum phosphate in a Middle Pennsylvanian tonstein from Eastern Kentucky. Geological Society of America Abstracts with Programs 21, PA52.

Tripplehorn, D., Stanton, R.W., Ruppert, L.F., Crowley, S.S., 1991. Volcanic ash dispersed in the Wyodak-Anderson coal bed, Powder River Basin, Wyoming. Organic Geochemistry 17, 567-575.

Twitchett, R.J., 2006. The palaeoclimatology, palaeoecology and palaeoenviromental analysis of mass extinction events. Palaeogeography, Palaeoclimatology, Palaeoecology 232, 190-213.

Twitchett, R.J., Looy, C.V., Morante, R., Visscher, H., Wignall, P.B., 2001. Rapid and synchronous collapse of marine and terrestrial ecosystems during the end-Permian biotic crisis. Geology 29, 351-354.

Van Wees, J.D., Arche, A., Beijdorff, C.G., López-Gómez, J., Cloetingh, S.A.P.L., 1998. Temporal and spatial variations in tectonic subsidence in the Iberian Basin (eastern
Spain): inferences from automated forward modelling of high-resolution stratigraphy (Permian-Mesozoic). Tectonophysics 300, 285-310.

Vargas, H., Gaspar-Escribano, J., López-Gómez, J., Van Wees, J.D., Cloetingh, S., De La Horra, R., Arche, A., 2009. A comparison of the Iberia and Ebro basins during the Permian and Triassic, eastern Spain: a quantitative subsidence modelling approach. Tectonophysics 474, 160-183.

Vieillard, P., Tardy, Y., Nahon, D., 1979. Stability fields of clays and aluminum phosphates: parageneses in lateritic weathering of argillaceous phosphatic sediments. American Mineralogist 64, 626-634.

Virgili, C., Sopeña, A., Ramos, A., Hernando, S., 1977. Problemas de la cronoestratigrafia del Trias en España. Cuadernos de Geologia Iberica 4, 57-88.

Visscher, H., 1971. The Permian and Triassic of the Kingscourt outlier, Ireland. A Palynological Investigation Related to Regional Stratigraphical Problems in the Permian and Triassic of Western Europe: Special Paper of the Geological Survey of Ireland, 1, pp. 1-114.

Ziegler, P.A., 1988. Post-Hercynian plate reorganization in the Tethys and Artiic-North Atlantic domains. In: Manspeizer, W. (Ed.), Triassic-Jurassic Rifting. Developments in Geotectonics, 22. Elsevier, Amsterdam, pp. 711-755.

Ziegler, P., Sampfli, G.M., 2001. Late Palaeozoic-Early Mesozoic plate boundary reorganization: collapse of the Variscan orogen and opening of Neotethys. In: Cassinis, G. (Ed.), Permian Continental Deposits of Europe and other areas: Regional Reports and Correlations. Natura Bresciana. Monography, 25, pp. 17-34. 